\title{
ALTERAÇÕES BIOQUÍMICAS EM PLANTAS DE MILHO INFECTADAS PELO FITOPLASMA DO ENFEZAMENTO VERMELHO
}

\section{ANA CAROLINA BRUNO JUNQUEIRA}

\author{
Dissertação apresentada à Escola Superior de \\ Agricultura "Luiz de Queiroz", Universidade de \\ São Paulo, para obtenção do título de Mestre \\ em Agronomia, Área de Concentração: \\ Fitopatologia.
}

$P$ IR A C ICABA

Estado de São Paulo - Brasil

Setembro- 2003 


\section{ALTERAÇÕES BIOQUÍMICAS EM PLANTAS DE MILHO INFECTADAS PELO FITOPLASMA DO ENFEZAMENTO VERMELHO}

\section{ANA CAROLINA BRUNO JUNQUEIRA \\ Engenheiro Agrônomo}

Orientador: Prof. Dr. IVAN PAULO BEDENDO

Dissertação apresentada à Escola Superior de
Agricultura "Luiz de Queiroz", Universidade de
São Paulo, para obtenção do título de Mestre
em Agronomia, Área de Concentração:
Fitopatologia.

PIRACICABA

Estado de São Paulo - Brasil

Setembro - 2003 


\section{Dados Internacionais de Catalogação na Publicação (CIP)} DIVISÃO DE BIBLIOTECA E DOCUMENTAÇÃO - ESALQ/USP

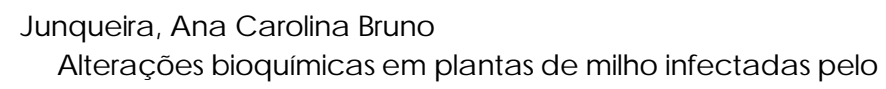

1. Bioquímica vegetal 2. Enfeza mento (doença de planta) 3. Fitoplasma 4. Milho I. Título

CDD 633.15

\section{"Permitida a cópia total ou parcial deste documento, desde que citada a fonte - $\mathrm{O}$ autor"}


Ao Gustavo,

Maria Clara e Gabriel e aos meus pais

pelo apoio e compreensão,

com amor,

DEDICO 


\section{AGRADECIMENTOS}

Ao Prof. Ivan Paulo Bedendo, pela orientação desta dissertação, paciência e amizade;

Ao Prof. Sérgio F. Pascholati, pela colaboração no trabalho, pelos muitos momentos dedicados e pela concessão do uso do laboratório de Fisiologia do Parasitismo, para realização dos trabalhos de análises bioquímicas e a Elaine e Robson pela grande ajuda prestada na realização deste trabalho;

Aos colegas do curso de Pós-graduação em Fitopatologia, por todo o apoio durante a realização deste estudo e em especial aos colegas do Laboratório de Fitopatologia Molecular, Adriana, Marília, Ana Paula e Luis;

A Capes pela concessão de bolsa de estudos durante o curso de Mestrado;

A todos aqueles que direta ou indiretamente contribuíram para a realização deste trabalho;

Finalmente, agradeço à minha família por todo o carinho, incentivo e compreensão. 


\section{SUMÁRIO}

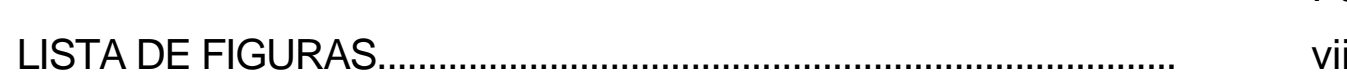

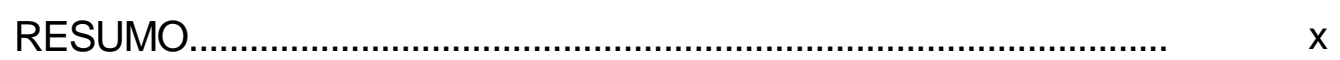

SUMMARY ................................................................................... xii

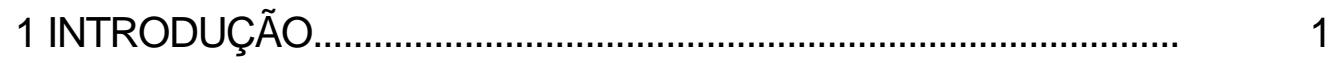

2 REVISÃO DE LITERATURA......................................................... 3

$2.1 \mathrm{O}$ enfezamento vermelho do milho.................................................. 3

2.1.1 Histórico e importância ................................................................ 3

2.1.2 Etiologia e transmissão ............................................................ 5

2.1.3 Sintomatologia e diagnose......................................................... 6

2.2 Alterações bioquímicas em interações plantas-fitopatógenos.......... 7

2.2.1 Alterações bioquímicas e fisiológicas em interações plantas- 14 fitoplasma.

2.2.2 Alterações morfológicas e em reguladores do crescimento 18 resultantes de interações plantas-fitoplasmas

3 MATERIAL E MÉTODOS.

3.1 Análise de proteínas e fenóis totais e das enzimas B-1,3glucanase e quitinase em 9 híbridos de milho infectados pelo fitoplasma do enfezamento vermelho

3.2 Análise de clorofila total, açúcares redutores, proteínas e fenóis totais e das enzimas peroxidase, ß-1,3 glucanase e quitinase em dois híbridos de milho infectados pelo fitoplasma do enfezamento vermelho.

3.3 Obtenção de populações sadias e infectivas do vetor. 
3.4 Detecção de fitoplasma em plantas inoculadas de milho................... 23

3.5 Testes bioquímicos................................................................... 25

3.5.1 Metodologia para dosagem de proteínas totais............................. 25

3.5.2 Metodologia para dosagem de açúcares redutores....................... 25

3.5.3 Metodologia para dosagem de clorofila total................................ $\quad 26$

3.5.4 Metodologia para dosagem de fenóis totais.................................. 26

3.5.5 Metodologia para a determinação das atividades de quitinase e 27 $\beta-1,3$ glucanase.

3.5.6 Metodologia para a determinação da atividade de peroxidase ..... 28

4 RESULTADOS DISCUSSÃO........................................................... 30

4.1 Conteúdo de proteínas e fenóis totais e atividades de $\beta-1,3$ glucanase e quitinase em nove híbridos de milho infectados pelo fitoplama do enfezamento vermelho.............................................. 30

4.2 Teores de clorofila total, açucares redutores, proteínas e fenóis totais, $\beta-1,3$ glucanase e quitinase em dois híbridos de milho infectados pelo fitoplasma............................................................. 36

4.2.1 Clorofila total........................................................................... $\quad 36$

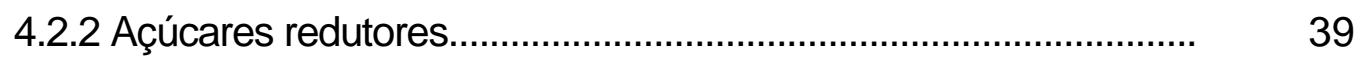

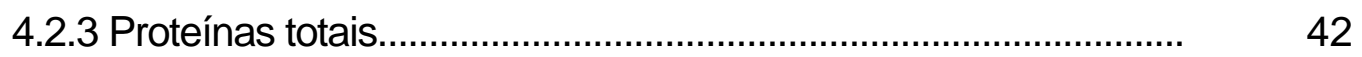

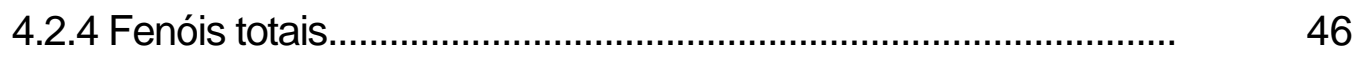

4.2.5 Peroxidase ............................................................................ 50

4.2.6 $\beta$-1,3 glucanase e quitinase...................................................... 53

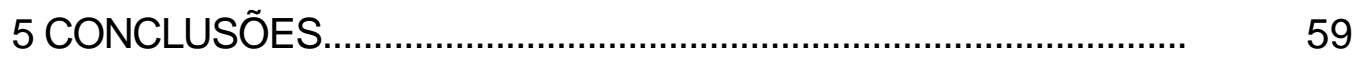

REFERÊNCIAS BIBLIOGRÁFICAS.................................................... 60 


\section{LISTA DE FIGURAS}

Página

1 Conteúdo de proteínas totais em nove híbridos comerciais de milho inoculados experimentalmente com o fitoplasma do enfezamento vermelho. Amostras de folhas para análise foram coletadas em plantas com 80 dias após a emergência

2 Atividade de ß-1,3 glucanase em nove híbridos comerciais de milho inoculados experimentalmente com o fitoplasma do enfezamento vermelho. Amostras de folhas para análise foram coletadas em plantas com 80 dias após a emergência.

3 Atividade de quitinase em nove híbridos comerciais de milho inoculados experimentalmente com o fitoplasma do enfezamento vermelho. Amostras de folhas para análise foram coletadas em plantas com 80 dias após a emergência

4 Conteúdo de fenóis totais em nove híbridos comerciais de milho inoculados experimentalmente com o fitoplasma do enfezamento vermelho. Amostras de folhas para análise foram coletadas em plantas com 80 dias após a emergência. 
5 Variação média percentual no conteúdo de proteínas e fenóis totais e nas atividades das enzimas ß-1,3 glucanase e quitinase em tecidos de plantas de milho inoculadas com o fitoplasma, em relação æ̀ plantas sadias

6 Conteúdo de clorofila total resultante da infecção pelo fitoplasma, em dois híbridos de milho, XLX 520 (suscetível) e FT9006 (resistente ).....

7 Conteúdo de açúcares redutores resultante da infecção pelo fitoplasma, em dois híbridos de milho, XLX 520 (suscetível) e FT9006 (resistente )

8 Conteúdo de proteínas totais resultantes da infecção pelo fitoplasma, em dois híbridos de milho, XLX 520 (suscetível) e FT9006 (resistente).

9 Variação média percentual no conteúdo de clorofila total, açúcares redutores e proteínas totais observada nos tecidos de folhas de plantas de milho inoculadas com fitoplasma, em relação æ̀s plantas sadias, em dois híbridos de milho, XLX 520 (suscetível) e FT 9006 (resistente).

10 Conteúdo de fenóis totais resultante da infecção pelo fitoplasma, em dois híbridos de milho, XLX 520 (suscetível) e FT9006 (resistente) 
11 Variação média percentual no conteúdo de fenóis totais em tecidos de folhas de plantas de milho inoculadas com fitoplasma, em relação às plantas sadias, em dois híbridos, XLX 520 (suscetível) e FT 9006 (resistente)

12 Atividade de peroxidase resultante da infecção pelo fitoplasma, em dois híbridos de milho, XLX 520 (suscetível) e FT9006 (resistente)

13 Atividade de ß-1,3 glucanase resultante da infecção pelo fitoplasma, em dois híbridos de milho, XLX 520 (suscetível) e FT9006 (resistente).

14 Atividade de quitinase resultante da infecção pelo fitoplasma, em dois híbridos de milho, XLX 520 (suscetível) e FT9006 (resistente)

15 Variação média percentual na atividade das enzimas peroxidase, ß1,3 glucanase e quitinase em tecidos de folhas de plantas de milho inoculadas com fitoplasma em relação a plantas sadias, em dois híbridos de milho, XLX 520 (suscetível) e $\quad$ FT 9006 (resistente). 


\title{
ALTERAÇÕES BIOQUÍMICAS EM PLANTAS DE MILHO INFECTADAS PELO FITOPLASMA DO ENFEZAMENTO VERMELHO
}

\author{
Autor: ANA CAROLINA BRUNO \\ Orientador: Prof. Dr. IVAN PAULO BEDENDO
}

\section{RESUMO}

O enfezamento vermelho do milho, causado por um fitoplasma, é uma das mais importantes doenças da cultura. Os danos ocasionados são relevantes, resultando em perdas econômicas significativas. Aspectos relacionados à interação milho-fitoplasma têm sido pouco investigados e, por consequência, são escassas as informações sobre alterações fisiológicas e bioquímicas que ocorrem no hospedeiro. $\mathrm{O}$ objetivo do presente trabalho foi justamente estudar as alterações bioquímicas que ocorrem em plantas de milho infectadas pelo agente causal do enfezamento vermelho. $O$ trabalho foi desenvolvido em duas etapas. Na primeira, foram determinadas as alterações no conteúdo de proteínas e fenóis e na atividade das enzimas B-1,3 glucanase e quitinase em nove híbridos comerciais de milho, experimentalmente inoculados com o fitoplasma. Na segunda etapa, dentre os nove híbridos, foram selecionados o mais resistente e o mais suscetível, sendo feita avaliação das alterações de proteínas, fenóis, clorofilas, açúcares redutores, peroxidase, B-1,3 
glucanase e quitinase em plantas infectadas pelo fitoplasma. Os ensaios foram conduzidos em casas teladas, sendo as plantas inoculadas aos 10 dias após a semeadura, através de 7-10 insetos infectivos da cigarrinha Dalbulus maidis por planta. A partir do aparecimento dos sintomas, amostras de folhas foram analisadas periodicamente para as determinações dos parâmetros bioquímicos. Para os nove híbridos, foi demonstrado um aumento médio de $20 \%$ no teor de proteínas, $90 \%$ de fenóis, $140 \%$ de quitinase e de $160 \%$ de $\beta-1,3$ glucanase, em plantas inoculadas. Nos ensaios com os híbridos resistente e suscetível inoculados, os resultados mostraram que houve um aumento em todos os parâmetros bioquímicos avaliados, exceção feita à clorofila, cujo teor foi reduzido em função da infecção pelo patógeno. De modo geral, os valores obtidos para os diferentes parâmetros foram mais elevados no híbrido suscetível quando comparados ao híbrido resistente. O aumento das concentrações de proteínas, açúcares redutores e fenóis em plantas inoculadas revela alteração nos processos metabólicos do hospedeiro decorrentes da infecção pelo patógeno. Alterações nas atividades enzimáticas parecem fazer parte de uma resposta inespecífica de defesa. A redução na quantidade de clorofila total indica que 0 fitoplasma pode interferir no mecanismo fotossintético, podendo levar ao aceleramento do processo de senescência foliar. 


\title{
BIOCHEMICAL CHANGES IN CORN PLANTS INFECTED BY THE MAIZE BUSHY STUNT PHYTOPLASMA
}

\author{
Author: ANA CAROLINA BRUNO JUNQUEIRA \\ Adviser: Prof. Dr. IVAN PAULO BEDENDO
}

\section{SUMMARY}

Maize bushy stunt, caused by a phytoplasma, is an important disease of corn crop. The damages are relevant, resulting in significant economic losses. Aspects related to corn-phytoplasma interaction has been little investigated and consequently information about physiological and biochemical alterations that occur in the host are rare. Thus, the objective of the present work was to study biochemical alterations that occur in corn plants infected by the maize bushy stunt phytoplasma. The work was carried out on two steps. First, using 9 commercial hybrids, alterations in the levels of protein and phenol and in the activities of the enzymes $\beta-1,3$ glucanase and chitinase, in plants inoculated with the phytoplasma were determinated. In the second step, among the 9 hybrids the most resistant and the most susceptible one was selected and changes in protein, phenol, clorophyl, reducing sugar, peroxidase, $\beta-1,3$ glucanase and chitinase in infected plants. were evaluated. The experiments were carried out 
inside greenhouse, and the corn plants were inoculated by using infective Dalbulus maidis leafhoppers 10 days after seeding. When symptoms started to appear, leaf samples were harvested at different times for the biochemical analyses. It was shown an average increase of $20 \%$ in protein and $90 \%$ in phenol content and increases around $140 \%$ and $160 \%$ in the activities of chitinases and $\beta-1,3-$ glucanases, respectively, in all 9 hybrids tested. When only the most susceptible and resistant hybrids were inoculated, the results showed an increase in all biochemical parameters evaluated, with exception for the chlorophyll content that decreased. In a general way, the values observed for the compounds and enzyme activities were higher in the susceptible hybrid when compared to the resistant one. The increases in protein, reducing sugar and phenol contents in inoculated plants point out changes in host metabolism due to the phytoplasma. The changes in enzyme activity seems to be an unspecific response of the plant to the pathogen and the reduction in chlorophyll content shows that the phytoplasma can interfere in photosynthesis and perhaps speedy senescence in the leaf tissue. 


\section{INTRODUÇÃO}

No Brasil, uma das mais importantes doenças do milho está associada a um fitoplasma, agente do enfezamento vermelho. Esse patógeno pode ocorrer de forma isolada ou em associação com espiroplasma e vírus. Avaliações mostraram reduções de até $100 \%$ na produtividade em áreas sob infestação natural do complexo do enfezamento, em diferentes híbridos comercias, evidenciando a importância da doença para cultura.

O desenvolvimento da infecção provocada pelo agente do enfezamento vermelho envolve alterações fisiológicas e bioquímicas nas plantas de milho. No entanto, relatos sobre estas alterações são escassos. Os mecanismos envolvidos na resistência de plantas de milho a este fitoplasma, bem como os mecanismos associados com 0 ataque do patógeno são muito pouco conhecidos.

Os efeitos mais freqüentemente investigados em outras interações planta-fitoplasma têm se relacionado à alterações no balanço hormonal, produção de toxinas, comprometimento da translocação de seiva pelos vasos do floema e redução na translocação de carboidratos e de nitrogênio. Pouca atenção tem sido dada a alterações em atividades enzimáticas, especialmente àquelas relacionadas à ativação de mecanismos de defesa pela planta, como as $B-1,3$ glucanases, quitinases e peroxidases.

Em razão da importância do enfezamento vermelho para a cultura do milho e da escassez de informações sobre os aspectos fisiológicos e bioquímicos relacionados à doença, o presente trabalho teve por objetivo investigar algumas alterações provocadas pelo fitoplasma através da avaliação dos níveis de proteínas, fenóis, açúcares redutores, clorofila e das enzimas B- 
1,3 glucanases, quitinases e peroxidases em plantas de milho experimentalmente infectadas. 


\section{REVISÃO DE LITERATURA}

\subsection{O enfezamento vermelho do milho}

\subsubsection{Histórico e importância}

Os primeiros relatos sobre a ocorrência do enfezamento foram feitos em meados da década de 40 (Alstatt, 1945), sendo a doença observada em plantios de milho localizados no vale do Rio Grande, no Texas (USA). Alguns anos mais tarde, Maramorosch (1955) descreveu dois tipos de enfezamento no México, denominados de enfezamento vermelho e pálido. A forma vermelha, chamada também do tipo Mesa Central, e a pálida, designada como tipo Rio Grande (Costa et al, 1971). Atualmente, o complexo do enfezamento, causado por fitoplasma (enfezamento vermelho) e espiroplasma (enfezamento pálido), ocorre em praticamente todas as áreas tropicais e subtropicais do continente americano, abrangendo o Sul dos Estados Unidos (Gordon et al., 1981), México (Davis, 1973), Peru (Nault et al, 1979), Venezuela (Lastra \& Trujillo, 1977), Nicarágua e Costa Rica (Vandemeer \& Poweer, 1990), El Salvador (Anaya Garcia, 1975), Argentina (Lenardon et al., 1993) e Brasil (Costa et al., 1971).

No Brasil, ambas as formas de enfezamento são conhecidas, desde o ínicio dos anos 70, quando foram consideradas de importância secundária. Kitajima \& Costa (1972) reconheceram que estas doenças representavam um problema de menor importância para a cultura do milho no Brasil, no entanto, foi enfatizado que poderíam causar sérios prejuízos se o milho fosse plantado tardiamente. 
A partir da metade da década de 80 , começou a se difundir a cultura de milho de sequeiro plantado fora da época normal, a qual ficou conhecida como milho "safrinha". Esta modalidade de cultivo passou, em poucos anos, de uma área inexpressiva para aproximadamente 1 milhão e 500 mil hectares, tornando o milho, a principal cultura de outono-inverno nos Estados de São Paulo, Mato Grosso do Sul e Goiás (IAC, 1998). Devido à difusão dessa prática, mudaramse as condições favoráveis a ocorrência do enfezamento, provavelmente, pelo fato do milho ser cultivado numa época em que as condições de alta umidade e temperatura favorecem o aumento da população da digarrinha vetora (Massola Junior et al., 1997). Nestas condições, a incidência dos enfezamentos tem sido alta, podendo provocar perdas significativas de produção (Massola Júnior et al., 1997). Este quadro, inicialmente restrito ao milho safrinha, passou a ser observado para os plantios tradicionais do milho realizados em outubronovembro, inclusive atingindo novas áreas localizadas fora daquelas anteriormente mencionadas (Bedendo, 1997). Nos dias atuais, os enfezamentos estão listados entre as mais importantes doenças do milho, tanto devido às perdas constantes que vêm causando, como por se constituírem em fator limitante para a produção, em função da região e da variedade/híbrido escolhidos para o plantio (Bedendo, 1997).

Estimativas confiáveis dos prejuízos causados por patógenos constituem-se num pré-requisito para o desenvolvimento de programas de controle de doenças, independentemente do método a ser utilizado. É desejável que se conheça o valor do prejuízo, pois só assim, em conjunção com o custo de controle, uma decisão racional e econômica pode ser adotada. Neste sentido, Massola Júnior. (1998) verificaram reduções de até 30\% na produtividade em parcelas sob infestação natural do complexo de enfezamento em comparação æ̀ tratadas com inseticidas, justificando a busca por métodos de controle efetivos. 
Levantamentos feitos por Oliveira et al. (1998) evidenciaram índices de incidência de até $100 \%$, levando à perda quase total da produção de campos comercias de milho localizados na região do Brasil-Central.

\subsubsection{Etiologia e transmissão}

As doenças conhecidas como amarelos eram atribuídas a vírus, no entanto, a partir de 1967 passaram a ser associadas com micoplasmas (MLO), atualmente denominados fitoplasmas (Davis, 1995b). Fitoplasmas são procariotos sem parede celular, pleomórficos, habitantes do floema e transmitidos por cigarrinhas.

O fitoplasma associado ao enfezamento vermelho, assim como os demais fitoplasmas, ainda não foram cultivados in vitro. Esse organismo foi relatado pela primeira vez em plantas de milho, por meio de microscopia eletrônica, em 1969 (Granados, 1969). Como não podem ser cultivados, os postulados de Koch ainda não foram preenchidos e os estudos de caracterização desses agentes ficaram, por algum tempo, restritos a testes biológicos envolvendo hospedeiros e vetores. Atualmente, as técnicas mais eficientes para detecção e identificação de fitoplasmas são a microscopia eletrônica, os testes de "Elisa", o emprego das amplificações de DNA através da chamada "reação em cadeia da polimerase" (PCR) e o uso da técnica de RFLP "Restriction Fragment Lengtht Polymorphism" (Harrison et al., 1996, Bedendo et al., 1997). Através de técnicas de PCR e RFLP, foi constatado que o fitoplasma que causa o enfezamento vermelho no Brasil é geneticamente similar ao agente da doença conhecida como "Maize Bushy Stunt" (MBS) que ocorre nos EUA (Bedendo et al.,1997).

Em condições naturais, a transmissão do fitoplasma tem sido relatada como sendo exclusivamente feita por insetos do tipo cigarrinha. Dalbulus maidis (DeLong \& Wolcott) tem sido relatada como a principal espécie vetora do fitoplasma (Nault, 1980). A característica desses insetos de se alimentarem no 
floema está diretamente relacionada com àaquisição desse patógeno, o qual é estritamente um habitante do floema (Granados, 1969). Além dessas cigarrinhas serem responsáveis pela transmissão do fitoplasma, é frequentemente observada a transmissão simultânea do espiroplasma e do vírus do "Rayado Fino" (Gámez \& Leon, 1985).

Em plantios sucessivos de milho, cigarrinhas pertencentes a espécie $D$. maidis migram de campos com enfezamento para outros campos com plantas jovens, disseminando a doença, mesmo a longas distâncias (Oliveira \& Oliveira, 1998). Os picos populacionais têm sido constatados em campos de milho durante os meses de março e abril (Oliveira et al., 1997).

\subsubsection{Sintomatologia e diagnose}

A sintomatologia apresentada por plantas infectadas pelo fitoplasma se caracteriza sobretudo pelo avermelhamento foliar (Bedendo, 1999). Os primeiros sintomas são de clorose dos bordos da folha, seguida de avermelhamento dos ápices e áreas marginais das folhas mais velhas. Numerosas espigas de tamanhos reduzidos podem se formar em plantas enfezadas. Brotações na forma de perfilhos podem aparecer nas axilas das folhas e na base das plantas. Outros sintomas, como redução do porte da planta, afinamento do colmo e encurtamento de entrenós também podem ocorrer (Schurtleff, 1986). Nault (1980) demonstrou que o quadro sintomatológico das plantas afetadas pelo enfezamento é variável, em função do genótipo do hospedeiro e das condições do ambiente.

A detecção de fitoplasmas constitui importante suporte para a diagnose das doenças. A disponibilidade de métodos rápidos, sensitivos e acurados, tem sido de grande valia para complementar diagnose baseada em sintomas.

A técnica de PCR usando "primers" derivados de sequências do gene de 16S rRNA tem se mostrado sensível para fins de detecção de fitoplasmas em plantas e insetos (Gundersen \& Lee, 1996). O PCR tem sido amplamente 
utilizado para comprovação de diagnoses de doenças em plantas presumivelmente infectadas e para a identificação de fitoplasmas (Davis, 1995a). Além de sua utilidade na detecção e suas implicações na diagnose, métodos moleculares são úteis na diferenciação e identificação de fitoplasma. Nesse sentido, num trabalho clássico, Lee et al. (1998) classificaram os fitoplamas em 14 grupos distintos e mais 41 subgrupos, empregando as técnicas de PCR e de RFLP (Restricion Fragment Length Polymorphism). De acordo com os autores, o fitoplasma do enfezamento do milho pertence ao grupo $16 \mathrm{~S}$ rDNA-1, subgrupo $\mathrm{B}$.

\subsection{Alterações bioquímicas em interações plantas-fitopatógenos}

A célula da planta, ao ser invadida por um patógeno, pode desencadear uma série de mecanismos de defesa na tentativa de conter o agente agressor. Estes mecanismos podem ser de natureza estrutural ou bioquímica, podendo promover, por exemplo, o desenvolvimento de caloses e papilas, ou ainda ocasionar a morte da célula levando também àmorte do invasor. Há casos em que a parede celular torna-se mais rígida, através da intensa lignificação, dificultando a progressão do agente agressor para as demais partes da planta (Pascholati \& Leite, 1995).

Além dessas barreiras estruturais da planta, utilizadas na contenção do patógeno, há também barreiras químicas, resultantes do metabolismo secundário do vegetal. Entre os mecanismos de resistência bioquímicos préformados, destaca-se a ocorrência de glicosídeos cianogênicos e fenólicos, fenóis, alcalóides glicosídicos, lactonas insaturadas, fototoxinas, quitinases e B1,3 glucanases. Por outro lado, compostos como as fitoalexinas, e proteínas relacionadas à patogênese (proteínas-RP), que também fazem parte do arsenal de mecanismos de defesa, são formados após a infecção do tecido da planta (Pascholati \& Leite, 1994). 
Segundo Agrios (1997), as células e tecidos vegetais respondem aos danos ocasionados pelos patógenos, mediante uma série de reações bioquímicas, produzindo substâncias tóxicas em altas concentrações para inibir o desenvolvimento dos mesmos. Dentre essas substâncias estão incluídos a maioria dos compostos fenólicos, como os ácidos clorogênicos e cafeico, os produtos da oxidação dos compostos fenólicos e as fitoalexinas, que em sua maioria são também compostos fenólicos.

Várias espécies de plantas têm desenvolvido um tipo de mecanismo de resistência chamado de resistência sistêmica adquirida (RSA) em resposta à infecção por patógenos. Neste caso, a infecção inicial causada pelo patógeno promove na planta um aumento da sua RSA contra um amplo espectro de patógenos (Ryals et al. 1996). Os genes responsáveis pela RSA se expressam, através das proteínas-RP (Ward et al., 1991). Existem evidências que o acúmulo de genes da RSA estão diretamente envolvidos no estabelecimento do estado de resistência àdoença em plantas infectadas.

As proteínas-RP começaram a ser investigadas no início da década de 70, por van Loon e van Kammen (1970), como macromoléculas envolvidas em resistência induzida, tendo fumo-Tobacco mosaic vírus como patossistema modelo. Hoje, tem-se conhecimento que as proteínas-RP são produzidas por muitas plantas como resposta à infecção por patógenos (Sticher et al., 1997; Cordero et al., 1992) e podem ser induzidas por diferentes agentes infecciosos, tais como vírus, viróides, fungos e bactérias (Bol et al., 1990). Além destes agentes infecciosos, as proteínas-RP também são produzidas depois do tratamento com produtos químicos específicos, como ácido poliacrílico, derivados de aminoácidos, sais de metais pesados, ácido salicílico e poluentes do ar, durante alguns estádios normais do desenvolvimento de plantas e também pelo tratamento com alguns fitohormônios como auxina, citocinina, ácido abscísico e etileno (Mauch et al., 1992; Van Loon, 1985).

Geralmente as proteínas-RP se acumulam em plantas em resposta à infecção e em resposta àindução de resistência. Como se demonstrou estarem 
as proteínas-RP estreitamente relacionadas com o fenômeno da RSA, æ̀̀ vezes estas proteínas são denominadas de RSA-proteínas e os genes que são codificados para a síntese destas, são referidos como RSA-genes (Ward et al., 1991).

Com base em características serológicas, peso molecular e composição de aminoácidos, as proteínas-RP de fumo são separadas em cinco grupos (Stintizi et al., 1993; Sticher et al., 1997). As mais comumente investigadas são PR-1 (formas ácidas RP-1a, -1b e -1c e a forma básica RP -1g), PR-2 ( $\beta-1,3$ glucanases), PR-3 (quitinases), PR-4 (proteínas $r 1, r 2$ e s2 isoladas de folhas de fumo infectadas com TMV) e PR-5 (osmotina e n-osmotina). As proteínasRP acumulam-se em locais de infecção e em sítios distantes destes, em casos de indução de resistência sistêmica (Sticher et al., 1997). Sua síntese e acúmulo possuem, pois, caráter de resposta ativa e de sistemicidade, em casos de resistência induzida (Bol et al., 1990).

Em milho, várias proteínas-RP, como $\beta-1,3$ glucanases e quitinases têm sido encontradas acumuladas em folhas depois do tratamento com cloreto de mercúrio, infecção pelo Brome mosaic vírus, uso de etileno e outros elicitores (Nasser et al., 1988). As ß-1,3 glucanases e quitinases são enzimas líticas que hidrolisam as $B-1,3$ glucanas e a quitina (um polímero de $\mathrm{N}$-acetilglicosamina), respectivamente (Pascholati \& Leite, 1994).

Morris et al. (1998) estudaram mecanismos de defesa contra patógenos em milho, avaliando indutores químicos de resistência e expressão de genes relacionados à defesa da planta. Resultados mostraram que indutores químicos, como o acibenzolar-S-methyl (BTH) e 2,6,ácido dicloroisonicotínico (INA) são ativos em milho. Estes aumentaram a resistência contra oídio e ativaram a expressão dos genes PR-1 e PR-5 no milho. Estes genes foram coordenadamente ativados e funcionaram como indicadores de resposta de defesa da planta. Observou-se que estes genes são mais rapidamente e mais fortemente induzidos em uma interação incompatível do que em uma interação compatível. 
As enzimas $\beta-1,3$ glucanases e quitinases, como fatores de defesa da planta, atuam através do seu efeito inibitório sobre o patógeno. Evidências deste tipo de atuação foram obtidos in vitro, em ensaios que demonstraram a inibição no crescimento de fungos, quando na presença destas enzimas (SelaBuurlage, 1993). A expressão de $\beta-1,3$ glucanases e quitinases em resposta à infecção pelo fungo Fusarium moniliforme durante a germinação em sementes de milho, bem como o acúmulo destas hidrolases em tecidos embrionários e vegetativos, foram estudados por Cordero et al. (1994). Esses autores verificaram uma indução coordenada da expressão de uma isoforma de $\beta-1,3$ glucanase e três isoformas de quitinase em resposta à infecção de $F$. moniliforme em plântulas de milho. Observaram também que a expressão de uma isoforma de ß-1,3 glucanase está correlacionada ao aumento no nível da transcrição de mRNA para esta particular isoforma. No entanto, uma segunda isoforma desta enzima, também expressa em tecidos do embrião e da radícula, não tiveram um aumento no seu nível de acúmulo depois da infecção pelo patógeno, sugerindo que estas enzimas além de desempenharem um papel na defesa da planta, estavam presentes naturalmente no processo de germinação da semente do milho, exercendo um papel regulatório no desenvolvimento das mesmas.

Estudo similar foi feito com grãos de milho no estádio leitoso, experimentalmente infectados com Aspergillus flavus. Algumas isoformas de quitinase e ß-1,3 glucanase foram encontradas tanto em grãos infectados como naqueles livres do patógeno, enquanto outras isoformas herdáveis ou induzidas estavam presentes apenas nos grãos infectados. Assim, como quitinases e B1,3 glucanases são constitutivamente expressas em folhas de milho e em outras plantas, estas enzimas podem não apenas estarem relacionadas à interação entre grãos de milho e A. flavus, mas fazerem parte do sistema regulatório de desenvolvimento ou, ainda, serem responsáveis pela defesa contra outros fungos e bactérias que não causam doença (Ji et al., 2000). Os 
resultados indicaram que somente isoformas particulares das duas enzimas hidrolíticas estão envolvidas na interação grãos de milho- $A$. flavus.

A enzima peroxidase, a qual está presente nos tecidos das plantas (Hoagland, 1990), é conhecida por participar de vários processos fisiológicos de grande importância. Ela cataliza a oxidação e a eventual polimerização de álcool hidroxicinâmico em presença de peróxidos de hidrogênio, originando lignina (Gaspar et al., 1982). As peroxidases participam da biossíntese do hormônio vegetal etileno (Asada,1992), da oxidação de compostos fenólicos, os quais acumulam-se em resposta à infecção (Fry, 1986), oxidação do ácido indolil-3-acético (AIA) (Hoagland, 1990) e na biossíntese de lignina (Abelles \& Biles, 1991). Segundo Asada (1992), a atividade desta enzima pode ser alterada em função da resistência ou suscetibilidade de diferentes hospedeiros na presença de diferentes patógenos.

Segundo Vance et al. (1980) e Hammerschmidt \& Kuc (1982), as peroxidases parecem ter um papel nas reações de defesa das plantas, porque a lignificação e o espessamento da parede celular são respostas bem conhecidas no ataque de patógenos e essas enzimas também podem ser responsáveis pelo último passo na união oxidativa de monômeros fenólicos na formação de polímeros da parede. Além disso, parecem ter um papel importante na indução de resistência (Mohan \& Kolattukudy, 1990), atuando como um mecanismo de defesa contra patógenos (Kerby \& Somerville, 1992).

O envolvimento das peroxidases em diferentes processos fisiológicos em uma planta superior indica a atuação de diferentes isoenzimas que podem ser separadas em formas ácidas e básicas por eletroforese, cromatografia de troca iônica ou focalização isoelétrica (Gaspar et al., 1982). Em milho, através de elefrorese em gel de poliacrilamida, Hamil \& Brewbaker (1969) observaram 24 isoenzimas em extratos obtidos de 250 variedades. Grison \& Pilet (1985) relataram 11 isoperoxidases na fração citoplasmática extraída de raízes de milho e Lusso (1989) encontrou 10 isoenzimas em extratos de folhas de milho 
inoculadas com Helminthosporium carbonum, Helminthosporium maydis ou injuriadas mecani camente com carborundo.

Shimoni et al. (1991) mostraram que, após a infecção, a atividade da peroxidase aumentou mais rapidamente em cultivares de milho resistentes à infecção por Exserohilum turcicum, do que naqueles suscetíveis. As cultivares suscetíveis tiveram um atraso na ativação de seu mecanismo de defesa, fazendo com que as plantas expressassem sintomas típicos. Os sintomas observados nas cultivares resistentes apareceram, em média, 10 dias após a inoculação e as lesões foram bem menores do que aqueles observados nas plantas suscetíveis. Ainda, inferiu-se através deste estudo, que cultivares resistentes não-inoculados possuíam uma determinada atividade de peroxidase, que podia estar em baixa concentração e ou inativada. No entanto, no momento da inoculação ocorreu ativação ou aumento da concentração da enzima, fazendo com que a planta expressasse seus mecanismos de defesa rapidamente. Já, as cultivares suscetíveis mostraram um aumento da atividade desta enzima mais tardiamente, favorecendo assim, o ataque do patógeno. Nesse sentido, Kuc \& Pressig (1984) enfatizaram que a rapidez e a magnitude com a qual ocorre a ativação dos mecanismos de defesa podem ser críticos para a expressão de resistência.

Em outros trabalhos conduzidos com milho (Shimoni et al., 1996) foi demonstrado que algumas isoenzimas de peroxidase e $\beta-1,3$ glucanase estavam correlacionadas com a resistência a Exserohilum turcicum e a expressão do gene se (concentração de açúcar). Assim, um padrão distinto de bandas de isoperoxidases e $\beta-1,3$ glucanase foi encontrado em isolinhas suscetíveis e resistentes, carregando o alelo se. Através dos dados obtidos nesse trabalho, foi sugerido o uso destes padrões isoenzimáticos como marcadores bioquímicos para detectar genótipos resistentes de milho.

Roncatto \& Pascholati (1998) avaliaram os mecanismos de ação de Saccaromyces cerevisiae no fenômeno de proteção de plantas contra fitopatógenos, demonstrando a capacidade de preparações da levedura em 
alterar o metabolismo de plantas de milho e de sorgo, com base na atividade da enzima peroxidase. As preparações de $S$. cerevisiae foram representadas por suspensões de células e seus respectivos filtrados, autoclavados ou não. A análise de extratos obtidos dessas gramíneas mostrou que suspensões de células e fltrados dessas suspensões, tratados termicamente ou não, foram efetivos em ocasionar alterações na atividade e no padrão eletroforético da peroxidase. No entanto, estes extratos apresentaram baixa atividade de peroxidase, indicando que alterações na atividade e perfil eletroforético da enzima das plantas eram decorrentes do próprio tecido vegetal. Esses autores sugeriram que as alterações ocorridas com a peroxidase, em resposta ao tratamento com a levedura, refletiram o "reconhecimento" dos metabólitos da levedura pelas células vegetais, acarretando uma alteração no metabolismo normal da planta.

Em relação aos compostos fenólicos, apesar de serem sintetizados por rotas metabólicas secundárias de plantas, sua importância é fundamental para o metabolismo vegetal (Strack, 1997). Nem todos os fenóis têm função conhecida, sendo que alguns deles parecem ser simples intermediários do metabolismo normal das plantas (Beckman, 2000). Os fenóis são produzidos em células especializadas distribuídas pelos tecidos, ao acaso ou em locais estratégicos. As enzimas dessa síntese são associadas ao retículo endoplasmático, o que permite que, logo após a produção, esses compostos sejam armazenados em vesículas, na sua forma original ou glicosilada. A compartimentalização é fundamental para o funcionamento das células, pois os fenóis são tóxicos e devem ser mantidos na sua forma reduzida. A descompartimentalização de fenóis pode levar àsua rápida oxidação, pela ação de peroxidases, em resposta a infecção. Fenóis que se mantêm livres no citoplasma podem ter ação tóxica tanto sobre patógenos como sobre a própria célula vegetal e contribuir para a reação de hipersensibilidade (Hrazdina, 1994; Isaac, 1992). 
Compostos fenólicos são bem conhecidos como susbstâncias fungitóxicas, antibacterinas e antiviróticas (Friend, 1981). O efeito inibitório de compostos fenólicos na germinação de esporos, crescimento micelial e produção de enzimas variam entre os diferentes grupos de fenóis. Dessa forma, os fenóis vêm sendo considerados como compostos que fazem parte do arsenal de defesa das plantas, podendo contribuir para o isolamento de um patógeno, ainda no sítio de infecção. Ao que parece, o acúmulo de fenóis ocorre seguindo duas etapas. A primeira, que leva ao acúmulo de fenóis ao redor do sítio de infecção, é rápida e não envolve síntese protéica. A segunda, envolve a síntese de compostos de ação mais específica, como, as fitoalexinas, em células que cercam o sítio de infecção (Nicholson \& Hammerschmidt, 1992). O acúmulo de fenóis em tecidos vegetais depende do patossistema, do nível de resistência do hospedeiro e, no caso de resistência induzida, do indutor (Nicholson \& Hammerschmidt, 1992).

Certos casos de resistência em milho são bons exemplos da importância de fenóis. A resistência a Cochliobolus heterostrophus em plantas de milho portadoras do gene $r h m$ envolve, quase que exclusivamente, fenilpropanóides (Nicholson \& Hammerschmidt, 1992). Plantas de milho e de sorgo resistentes a Peronosclerospora sorghi apresentam não só diferenças quantitativas, mas também qualitativas em seus compostos fenólicos (Anwar et al., 1995).

\subsubsection{Alterações bioquímicas e fisiológicas em interações plantas- fitoplasma}

Musetti et al. (2000) investigaram alterações da parede celular e de alguns compostos polifenólicos, como suberina e lignina, em plantas de maçã infectadas pelo fitoplasma agente da proliferação da maçã (AP) e em plantas de ameixa infectadas pelo fitoplasma da leptonecrose (PLN). Alterações em plantas de Cataranthus roseus infectadas com o fitoplasma da AP e PLN também foram estudadas. Alterações histológicas específicas na parede celular 
revelaram aumento na proporção de cutina, suberina e tanino em plantas de maçã e de ameixa infectadas pelos respectivos fitoplasmas. Nenhuma alteração destes compostos foi observada para plantas infectadas de $C$. roseus. Análises de polifenóis totais confirmaram um acentuado aumento destas substâncias em tecidos infectados, especialmente para as plantas de ameixa. Esses autores sugeriram que esses metabólitos podem exercer um papel importante na defesa de plantas infectadas.

Rudzinska \& Kaminska (1999) observaram fitoplasmas em vasos condutores, células companheiras e parênquima do ploema em plantas de Tagetes patula, Helichrysum bracteatum e Gladiolus sp com alterações típicas de infecção por fitoplasma. Nos poros das lâminas de vasos condutores, células fitoplasmáticas foram vistas, o que sugere que o transporte vertical desse patógeno ocorre nos vasos condutores através dos poros existentes. O contato dos vasos condutores com células vizinhas ocorre através dos plasmodesmas, para os quais nenhuma alteração foi observada em tecidos de plantas infectadas. O tamanho e a estrutura dos plasmodesmas ficaram inalterados, não permitindo a passagem de fitoplasma. Danos na parede celular foram observados através de cavidades onde os fitoplasmas estavam presentes. Danos no parênquima e células companheiras também foram visualizados. Células onde ocorriam danos nas paredes, estavam sempre associadas à presença de fitoplasma. As células de fitoplasma foram esporadicamente vistas nos espaços intercelulares do parênquima. Esses autores inferiram que o transporte horizontal estaria relacionado aos danos presentes nas paredes celulares de plantas infectadas, causados pelo próprio fitoplasma.

Guthrie et al. (2001) estudaram um modelo de patogenicidade associada ao fitoplasma do declínio do mamoeiro, baseado em alterações fisiológicas (troca gasosa, taxa respiratória e abertura estomatal) e bioquímicas (concentração de carboidratos) das plantas. Nesse estudo, constataram que a taxa fotossintética (troca de $\mathrm{CO}_{2}$ ) nas folhas maduras foi reduzida em aproximadamente $50 \%$ nas plantas infectadas em relação æ̀ sadias, quando os 
primeiros sintomas estavam visíveis. Nestas folhas, o fechamento dos estômatos foi uma característica bastante evidente. Esse decréscimo na taxa fotossintética foi atribuído à redução na disponibilidade de $\mathrm{CO}_{2}$ devido ao fechamento estomatal, à diminuição da capacidade fotossintética ocasionada pela perda de clorofila ou àinibição da fotossíntese provocada pelo acúmulo de carboidratos nas folhas. Além disso, o completo fechamento dos estômatos em tecidos infectados não foi devido à deficiência hídrica, mas resultante do aumento de temperatura na folha e do bloqueio no transporte via xilema. Esses autores constataram também um aumento nos níveis de carboidratos em tecidos foliares de plantas doentes, mas um decréscimo nos tecidos do caule e da raiz. Esse fato foi explicado com base nos metabólitos do fitoplasma ou metabólitos produzidos pela planta hospedeira. O acúmulo de carboidratos nas folhas foi atribuído àbaixa contribuição das reservas foliares em relação ao teor de carboidrato total da planta (aproximadamente 5\%). Nesse trabalho foi proposto um modelo de patogenicidade para o declínio do mamoeiro, no qual ocorreria o bloqueio do floema e, portanto, o acúmulo de carboidratos nas folhas, resultando em decréscimo no caule e raízes.

Nesta mesma linha de trabalho, Scneider (1977) sugeriu que para o declínio da pereira, metabólitos tóxicos produzidos pelo fitoplasma ou pela planta hospedeira são translocados dos vasos mais novos (com numerosos fitoplasmas) para aqueles mais velhos (poucos ou nenhum fitoplasma). 0 envolvimento de metabólitos tóxicos móveis é proposto para explicar a aparente perda da funcionalidade do floema em plantas infectadas com título muito baixo de fitoplasma. Para esses agentes tóxicos, tem sido sugerido a mobilidade pelo xilema para explicar a expressão dos sintomas em folhas maduras livres do fitoplasma.

Oropeza et al. (1995) propuseram, para o amarelecimeto letal do coqueiro, que a aquisição do fitoplasma pela planta hospedeira através da cigarrinha vetora e sua limitada multiplicação ocorrem no floema. Esses organismos são transportados pelo fluxo da seiva elaborada para porções 
distantes do local onde o patógeno penetrou na planta. A restrição do transporte de seiva pelo floema pode causar stresse fisiológico nas raízes, resultando em produção de ácido abscíssico (ABA), em função de fechamento estomatal e redução na fotossíntese. Ainda, para plantas de coqueiro, Martinez et al. (2000) determinaram que o fechamento estomatal ocorre antes do aumento da concentração de ABA. Assim, a taxa fossintética diminuiu logo após esse fechamento, ocorrendo uma acentuada redução de pigmentos e proteínas fotossintéticas.

Para plantas doentes de fumo e vinca, Lepka et al (1999) verificaram aumento dos níveis de carboidratos e amido em folhas superiores, logo após a infecção pelo fitoplasma. No entanto, ocorreu um decréscimo destes carboidratos nas raízes. A infecção pelo fitoplasma teve pouco efeito nos níveis de aminoácidos, indicando que a translocação dos mesmos não foi praticamente afetada em plantas doentes.

León et al. (1996) observaram que plantas de coqueiro infectadas pelo fitoplasma, que causa o amarelecimento letal (LY), tiveram um decréscimo progressivo na condutância estomatal, com o desenvolvimento da doença. Em estágios iniciais da doença e antes que os sintomas de amarelecimento se iniciassem, a condutância estomatal foi reduzida em folhas do topo, meio e base da coroa do coqueiro. Esses autores sugeriram que o fechamento estomatal induzido pelo fitoplasma é o principal fator para o desenvolvimento dos sintomas, pois o fechamento dos estômatos altera a troca gasosa e outros processos relacionados, como movimento hídrico e fotossíntese na planta. Assim, a alteração no comportamento estomatal poderia ser considerada como um dos mecanismos de patogenicidade deste fitoplasma. Um segundo mecanismo, seriam as alterações bioquímicas, como redução na taxa fotossintética e redução nos níveis de proteínas, clorofilas e carotenóides. Estas alterações induzidas pelo fitoplasma associadas ao amarelecimento foliar, resultariam em um processo de senescência foliar. $O$ aumento na concentração de ácido abscíssico nas folhas e a formação de quantidades 
crescentes de etileno nos coqueiros doentes evidenciaram a ocorrência de um desbalanço hormonal, o qual poderia se constituir no terceiro mecanismo de patogenicidade.

\subsubsection{Alterações morfológicas e em reguladores do crescimento resultantes de interações plantas-fitoplasmas}

O envolvimento de reguladores de crescimento de plantas na patogênese de doenças de etiologia fitoplasmática tem sido especulado e 0 estabelecimento de um tipo de relação entre hormônios e desenvolvimento de sintoma tem sido investigado ao longo do tempo. Maramorosch (1957) usou ácido giberélico para promover reversão de sintomas em plantas de margaridinha que apresentavam sintomas de amarelo e em plantas de milho que exibiam sintomas de enfezamento pálido.

Ensaios conduzidos por Purohit et al. (1980) demonstraram que o aumento na quantidade de auxina estava relacionado com sintoma de filodia em plantas de Sesamum sp., infectadas por fitoplasma. Segundo esses autores, comparado com os tecidos sadios, o nível de auxina endógena foi alto em óvulos proliferados, flores com filodia, e brotação de ramos axilares.

Em plantas de vinca, infectadas com diferentes fitoplasmas, Davey et al. (1981) encontraram aumento nos níveis de citocinina endógena em flores com virescência, mas diminuição deste hormônio em raízes e folhas maduras. Aumento nos níveis de citocinina também foram constatados por Vizarova et al. (1984) em flores de Ribes houghtonianum infectadas com fitoplasmas, sugerindo um papel direcionado dos fitoplasmas na produção desse hormônio.

De acordo com Chang \& Lee (1995), não está totalmente esclarecido se os fitoplasmas causam distúrbio no balanço hormonal através indução na síntese adicional de hormônios pela planta, indução de consumo pelo hospedeiro ou através da interferência com a capacidade de síntese e/ou de translocação normal de hormônios pelas plantas infectadas. 
Sintomas do tipo filodia estão caracteristicamente associados a fitoplasmas. Como exemplo cita-se a filodia do trevo, a filodia de Cannabis, a filodia da Justicia, e a filodia de C. roseus. No entanto, são raros os relatos sobre alterações ao nível histológico, bem como sobre mudanças estruturais associadas a este sintoma (Chang \& Lee, 1995).

$\mathrm{Na}$ década de 40, foram registrados, para plantas de tomate e feijão, diferenciação das características morfológicas e anatômicas do carpelo para simples pecíolo (Dana, 1941). Em 1963, foram descritas alterações morfológicas em plantas de trevo, os quais apresentavam sintomas de filodia (Kreitlow, 1963). No entanto, somente em 1977, estudos histológicos foram conduzidos sobre estes tipos de anomalias. Chang (1977) iniciou os estudos de exame da estrutura de pétala, sépala, estilo e ovário de flores de $C$. roseus com filodia, através de cortes de tecidos ultrafinos examinados em microscópio de luz. Esse mesmo autor conduziu ensaios visando comparar histologicamente plantas sadias e infectadas com fitoplasmas, quanto æ̀ características associadas ao desenvolvimento de filodia e virescência. Em plantas de vinca, experimentalmente inoculadas com fitoplasma do superbrotamento do Sassafras albidum, foi demonstrada a ocorrência de alterações de tecido. Quatro estádios de transição de partes florais foram identificados. No primeiro estádio houve perda da coloração nas pétalas e um leve aumento do ovário. No segundo, as partes florais ficaram completamente verdes, enquanto os ovários assumiram uma característica do tipo folha. No terceiro, o porte floral foi grandemente reduzido, com o ovário e a antera tornando-se estruturas do tipo folha. No quarto estádio, essa alteração morfológica foi completa, não havendo mais evidência das partes reprodutivas. Esse estádio vegetativo permaneceu inalterado por toda a vida da planta. Houve diferenças pronunciadas na estrutura foliar de plantas sadias e de plantas doentes, sendo que o arranjo das células do parênquima paliçádico e esponjoso de folhas doentes se apresentaram de forma mais compacta que aquele das células de folhas sadias. 
Os cloroplastos foram encontrados nas pétalas de quarto estádio provenientes de plantas doentes, mas não foram encontrados em pétalas sadias. Este, provavelmente, é o principal efeito associado com filodia em $C$. roseus. A perda de coloração das pétalas do primeiro estádio foi acompanhada pelo aparecimento de cloroplastos e redução no tamanho. Os cloroplastos aumentaram em número durante o segundo e terceiro estádios até que as pétalas se tornassem completamente verdes. Embora não tenham ocorrido diferenças estruturais em tecidos de pétalas associadas com a infecção de fitoplasmas, houve uma intensa redução no seu tamanho. No quarto estádio, pétalas de plantas infectadas se tornaram estruturas semelhantes a folhas, onde o tecido da pétala se tornou essencialmente tecido de folha.

A falta de cloroplastos em pétalas de plantas sadias, bem como o desaparecimento da pigmentação da pétala, indicaram que a infecção por fitoplasmas afetou o controle do passo metabólito associado com a síntese de clorofila e o desenvolvimento de cloroplasto.

Secções ultrafinas de tecidos de sépalas revelaram que não ocorreu diferença anatômica entre tecidos de plantas livres de infecção e de plantas doentes. $O$ ovário normal de $C$. roseus se distinguiu principalmente do ovário de quarto estádio de plantas infectadas, pois este último perdeu sua integridade e se tornou indistinguível do tecido de folha. A alteração de todas estas características florais da planta infectada foi atribuída ao desbalanço hormonal provocado pela infecção do fito plasma. 


\section{MATERIAL E MÉTODOS}

\subsection{Análise de proteínas e fenóis totais e das enzimas B-1,3-glucanase e quitinase em nove híbridos de milho infectados pelo fitoplasma do enfezamento}

Foram utilizados 9 híbridos de milho, sendo eles: DO 02; XLX 520, AG 3010; FT 9043; Z 8452; P 3063; FT 9006; C 909 e P 3081.

As sementes de todos os híbridos foram pré-germinadas, visando padronizar a emergência das plântulas. Para isto, as sementes foram colocadas sobre papel umedecido disposto em bandejas, as quais foram cobertas por um filme de plástico transparente. O material foi levado para incubação em germinador regulado para $25{ }^{\circ} \mathrm{C}$, durante um período de 4 dias. As plântulas que apresentavam hipocótilo e radícula bem desenvolvidos foram transferidas para copos plásticos (250 mL), contendo como substrato uma mistura de solo, matéria orgânica e areia.

A inoculação das plantas com o patógeno foi feita aos 10 dias após o plantio, através do confinamento de 10 cigarrinhas infectivas em cada planta, durante 4 dias, usando-se cilindros plásticos. Ao final deste período, os cilindros foram retirados, e os insetos e ovos foram eliminados. Plantas mantidas livres de insetos serviram como testemunhas.

Vinte dias após a inoculação, as plantas crescidas nos copos foram transplantadas para sacos plásticos de $5 \mathrm{~L}$ (1planta/saco), contendo o mesmo tipo de substrato. A cada 20 dias foi feita aplicação de $12 \mathrm{~g}$ de sulfato de amônio acrescido da fórmula 4-14-8 (1:2) para cada saco contendo uma planta. 
Para realização dos testes bioquímicos, discos de tecido foliar de $1,5 \mathrm{~cm}$ de diâmetro foram amostrados a partir de folhas de mesma idade fisiológica, localizadas no terço médio das plantas de milho. As amostragens foram feitas quando as plantas apresentavam as espigas no ponto de colheita, correspondendo ao estádio 7, de acordo com a escala de Fancelli \& Lima (1992). As amostras foram coletadas, identificadas e armazenadas em congelador $\left(-20{ }^{\circ} \mathrm{C}\right)$ para posterior realização de testes bioquímicos para avaliação de fenóis totais, quitinase, $\beta$-1,3 glucanase e proteínas totais.

3.2 Análise de clorofila total, açúcares redutores, proteínas e fenóis totais, e das enzimas peroxidase, B-1,3 glucanase e quitinase em dois híbridos de milho infectados pelo fitoplasma do enfezamento

O ensaio foi conduzido com os híbridos: XLX 520 (suscetível) e FT 9006 (resistente). Estes híbridos foram escolhidos em função dos sintomas (Toffanelli, 2001) e das alterações bioquímicas obtidas no ensaio anterior.

A instalação e condução do experimento foram feitas seguindo-se a mesma metodologia descrita para o item 3.1. A única variação ocorreu na inoculação, pois neste ensaio foram confinadas 7 cigarrinhas por planta.

Para as análises bioquímicas, as amostras foram coletadas um dia antes da exposição das plantas aos insetos, considerado período 0 e aos 40, 50, 70 e 80 dias após a inoculação. Amostras de disco de tecido foliar foram obtidas de folhas de mesma idade fisiológica, situadas no terço médio de cada planta. As amostras foram coletadas, identificadas e armazenadas em congelador $\left(-4{ }^{\circ} \mathrm{C}\right)$ para posterior realização de testes bioquímicos para avaliação de proteínas totais, carboidratos, clorofila, fenóis totais, quitinase, ß-1,3 glucanase e peroxidase.

O ensaio foi feito através de um esquema fatorial $2 \times 2 \times 5$, representando dois híbridos (XLX 520 e FT 9006), 2 tratamentos (plantas inoculadas e não inoculadas) e 5 períodos de amostragem $(0,40,50,70$ e 80 dias após a 
inoculação). O ensaio foi conduzido com 3 repetições, onde cada planta representou 1 repetição. Os dados foram estatisticamente analisados através do programa ESTAT, desenvolvido junto a Unesp, campus Jaboticabal.

\subsection{Obtenção de populações sadias e infectivas do vetor}

A população sadia da cigarrinha $D$. maidis foi obtida através da coleta de adultos em culturas de milho. Estes insetos foram colocados para ovoposição em plantas sadias, com 4-6 folhas, durante um período de 5 dias. Um total de 25 insetos foi confinado por planta, através de cilindros plásticos. Antes da eclosão, os ovos foram removidos e depositados sobre novas plantas sadias. As ninfas nascidas destes ovos estavam livres de fitoplasma, pois este agente não é transmitido via transovariana. A população foi mantida em plantas acondicionadas em gaiolas teladas.

A obtenção da população infectiva foi feita a partir de ninfas de segundo e terceiro instares, as quais foram criadas em plantas sadias e, posteriormente, removidas para planta fonte de fitoplasma. Na planta fonte, com 80 dias de idade, as ninfas foram mantidas no cartucho, durante 4 dias, por meio de um saco de tecido do tipo voal. Após a fase de aquisição, as ninfas foram transferidas para plantas sadias mantidas no interior de gaiolas de criação, onde permaneceram por um período de 21 dias, correspondentes ao período de latência. A população infectiva foi mantida em plantas de milho pipoca da variedade Zélia, através de transferências sucessivas dos insetos.

\subsection{Detecção de fitoplasma em plantas inoculadas de milho}

A presença de fitoplasma nas plantas dos híbridos inoculados e a ausência do patógeno nas plantas testemunhas foram confirmadas por meio da técnica de reação em cadeia pela polimerase - PCR (Lee et al., 1993a). Amostras de folhas foram coletadas e a partir delas procedeu-se àextração de 
DNA total, de acordo com a metodologia de Lee et al. (1993b). As reações de PCR duplo para amplificação de fragmentos de DNA de fitoplasma foram conduzidas com os iniciadores universais R16 mF2/mR1 e R16 F2n/R2 (Gundersen \& Lee, 1996). Para um volume final de reação de $50 \mu \mathrm{L}$ foram usados as seguintes proporções de reagentes, segundo Lee et al. (1993a): $37,75 \mu \mathrm{L}$ de água; $1 \mu \mathrm{L}$ de cada iniciador (solução estoque de $20 \mathrm{~mL} / \mu \mathrm{L}$ ); $4 \mu \mathrm{L}$ de uma mistura de deoxinucleotídeos (solução estoque de 2,5 mM de cada deoxinucleotídeo); $5 \mu \mathrm{L}$ de tampão PCR (6,75 $\mathrm{mL}$ de água; $1 \mathrm{~mL}$ de $1 \mathrm{M}$ tris $\mathrm{pH}$ 8,3; 0,15 mL de $1 \mathrm{M} \mathrm{mgCl}$; $2 \mathrm{~mL}$ de 2,5 M KCL; 0,1\% de gelatina); 0,25 $\mu \mathrm{L}$ de amplitaq $5 \mathrm{U} / \mu \mathrm{L}$ (Perkin Elmer Co., Norwalk, CT). Um volume de 1,5 $\mu \mathrm{L}$ do extrato contendo DNA de planta foi adicionado aos demais componentes de cada reação.

As reações de PCR foram processadas em um aparelho termociclador (Perkin Elmer Cetus, Norwalk, CT). O programa estabelecido foi de 35 ciclos, sendo que cada ciclo compreendeu as seguintes etapas: denaturação 1 minuto ( 2 minutos para o primeiro ciclo) a $94^{\circ} \mathrm{C}$, anelamento 2 minutos a $50^{\circ} \mathrm{C}$ e extensão 3 minutos a $72^{\circ} \mathrm{C}$ (7 minutos para o último ciclo). Os produtos de PCR foram analisados através de eletroforese em gel de agarose (1\%), após coloração com brometo de etídio e visualização das bandas de DNA em um transiluminador de luz ultravioleta. O padrão de peso molecular utilizado foi 1Kb DNA ladder (Life Technologies, Gaithersburg, MD).

Os iniciadores universais que foram empregados nas reações de PCR foram desenvolvidos com base na sequência do 16S rRNA. As sequências de nucleotídeos para cada um destes iniciadores são assim especificadas: R16 MF1 - 5' AAG ACG AGG ATA ACA GTT GG 3'(Davis \& Lee, 1993); R16 mR1 5' TTC CCT CTT CTT GCG AAG TTA GGC CAC CGC 3'(Davis \& Lee, 1993); R16 F2n - 5' GAA ACG ACT GCT AAG ACT GG 3'(Gundersen \& Lee, 1996); R16 R2 -5' TGA CGG GCG GTG TGT ACA AAC CCC G 3' (Gundersen \& Lee, 1996). A detecção de fitoplama foi conduzida com o emprego de PCR duplo ("nested" PCR), sendo que na primeira reação foi usado o par de iniciadores 
R16 mF1/R16 mR1. O produto da primeira reação foi diluído na proporção de 1:50 em água e usado como molde para a segunda reação com o par R16 F2n/R2.

\subsection{Testes bioquímicos}

\subsubsection{Metodologia para a dosagem de proteínas totais}

As amostras de tecido foliar (0,3 $\mathrm{g}$ de tecido fresco) foram maceradas em almofariz com nitrogênio líquido até a obtenção de um pó fino e a elas foram adicionadas $5 \mathrm{~mL}$ de tampão fosfato $0,01 \mathrm{M}(\mathrm{pH}=6,0)$. Estas suspensões foram transferidas para tubos de centrífuga, onde foram centrifugados $(20.000 \mathrm{~g} / 25$ min. à $4^{\circ} \mathrm{C}$ ) e os sobrenadantes coletados com pipeta de "Pasteur". A seguir, $800 \mu \mathrm{L}$ de cada amostra coletada foi misturado, sob agitação, com $200 \mu \mathrm{L}$ de reagente de Bradford concentrado. Após 5 min., a absorbância foi lida a 595 nm, com o auxílio de um espectofotômetro e os resultados foram expressos como mg de proteína/g tecido fresco, tendo a albumina de soro bovino como proteína padrão (Bradford, 1976).

\subsubsection{Metodologia para a dosagem de açúcares redutores}

As amostras de tecido foliar (0,3 $\mathrm{g}$ de tecido fresco) foram maceradas em almofariz com nitrogênio líquido até a obtenção de um pó fino e a elas foram adicionadas $5 \mathrm{~mL}$ de tampão fosfato $0,01 \mathrm{M}(\mathrm{pH}=6,0)$. Estas suspensões foram transferidas para tubos de centrífuga e foram centrifugados $(20.000 \mathrm{~g} / 25 \mathrm{~min}$. à $4^{\circ} \mathrm{C}$ ) e os sobrenadantes coletados com pipeta de "Pasteur". Amostras com $500 \mu \mathrm{L}$ de cada tubo foram colocados em outros tubos de ensaio contendo 1,5 $\mathrm{mL}$ de PAHBAH (hidrazida do ácido p-hydroxibenzóico). Estes foram aquecidos em banho-maria $\left(100^{\circ} \mathrm{C}\right)$ por $5 \mathrm{~min}$, resfriados em gelo e tiveram sua absorbância a $410 \mathrm{~nm}$ lida em espectofotômetro e os resultados foram 
expressos em mg de glicose/g tecido fresco, tendo a glicose como carboidrato padrão (Lever, 1972).

\subsubsection{Metodologia para a dosagem de clorofila total}

As amostras de tecido vegetal $(0,2 \mathrm{~g}$ de tecido fresco) foram maceradas com nitrogênio líquido até a obtenção de um pó fino. Em seguida, foram adicionadas a estas amostras $10 \mathrm{~mL}$ de acetona $80 \%$, utilizada sempre a $4^{\circ} \mathrm{C}$. Todo o procedimento foi realizado protegendo-se as amostras da luz. A seguir, as amostras foram filtradas em papel de filtro Whatman $n^{\rho} 1$, sendo o volume completado para $50 \mathrm{~mL}$ com acetona $80 \%$. Determinourse a absorbância das amostras a 663 e 645 nm em espectofotômetro, sendo o conteúdo de clorofila total de cada amostra expresso em mg de clorofila/g tecido fresco (Arnon, 1949; Hammerschmidt \& Nicholson, 1977).

\subsubsection{Metodologia para a dosagem de fenóis totais}

Em tubos de ensaio contendo $10 \mathrm{~mL}$ de metanol acidificado (HCL 0,1\%), foram colocadas amostras de tecido vegetal (0,3 $\mathrm{g}$ de tecido fresco), sendo as mesmas homogeinizadas (homogeinizador modelo Sorvall) por 1 min e filtradas em papel de fitro Whatman $n^{\circ} 1$. O filtrado de cada amostra foi submetido a um evaporador rotativo $\left(40^{\circ} \mathrm{C}\right)$ com pressão negativa, e o resíduo resuspenso em 2 $\mathrm{mL}$ de água destilada. A seguir, adicionou-se $5 \mathrm{~mL}$ de hexana à amostra, seguido de agitação vigorosa, para a remoção total de clorofila e de outros pigmentos. Na seqüência, a hexana foi retirada com auxílio de uma pipeta "Pasteur" e o volume final completado para 2,5 mL com água destilada, do qual separou-se uma alíquota de $150 \mu \mathrm{L}$ que foi adicionada a $1,5 \mathrm{~mL}$ de solução de $2 \%$ de carbonato de sódio preparada no momento da dosagem.

Por último, acrescentourse $150 \mu \mathrm{L}$ do reagente Folin-Ciocalteau 2N (1:1; v/v), sob agitação suave. Decorridos 30 min, a absorbância das amostras foi 
determinada espectrofotometricamente a $750 \mathrm{~nm}$ e os resultados expressos como equivalentes de ácido clorogênico/g tecido fresco. (Campbell \& Campbell, 1986; Gayon, 1972; Harbone, 1989).

\subsubsection{Metodologia para a determinação das atividades de quitinase e $\beta-1,3$ glucanase}

Para determinar a atividade das enzimas quitinase e $\beta-1,3$ glucanase, 0 tecido foliar $(0,3 \mathrm{~g})$ foi macerado mecanicamente em almofariz com nitrogênio líquido, até a obtenção de um pó fino. A este pó foi acrescentado $4 \mathrm{~mL}$ de tampão acetato $100 \mathrm{mM} \quad(\mathrm{pH}=5,0)$, sendo em seguida, as amostras centrifugadas $\left(20.000 \mathrm{~g} / 25 \mathrm{~min}\right.$. / $\left.4^{\circ} \mathrm{C}\right)$. O sobrenadante de cada amostra foi coletado com o auxílio de uma pipeta "Pasteur" e transferidos para tubos de 2 $\mathrm{mL}$ (todo este procedimento foi realizado a baixa temperatura). Estes sobrenadantes foram utilizados como fonte enzimática para realização dos testes de atividade de quitinase e de ß-1,3 glucanase. A atividade da enzima quitinase foi avaliada através do uso de quitina carboximetilada marcada com remazol brilhante violeta ("CM-Chitin-RBV") como substrato, em espectofotômetro (550 nm), em função de fragmentos solúveis de "CM-ChitinRBV" liberados. Para um volume de $200 \mu \mathrm{L}$ da fonte enzimática foi misturado a $600 \mu \mathrm{L}$ do mesmo tampão de extração e $200 \mu \mathrm{L}$ de "CM-Chitin-RBV" (2mg/mL). Após incubação a $40^{\circ} \mathrm{C} / 20$ min., a reação foi paralisada com $200 \mu \mathrm{L}$ de $\mathrm{HCL}$ 1,0M, seguido de centrifugação (5000 g/ 5 min. a $\left.4^{\circ} \mathrm{C}\right)$. A absorbância (550 nm) do sobrenadante foi determinada a $30^{\circ} \mathrm{C}$ e os resultados foram expressos em unidades de absorção/minuto de incubação/ mg de proteína (Wirth \& Wolf, 1990).

A atividade da enzima $\beta-1,3$ glucanase, para amostras do ensaio 3.1, foi obtida através do uso de Curdlan como substrato, em espectofotômetro (600 $\mathrm{nm})$. Para um volume de $200 \mu \mathrm{L}$ da fonte enzimática foi misturado $400 \mu \mathrm{L}$ do mesmo tampão de extração e $200 \mu \mathrm{L}$ de Curdlan. Após incubação a $40^{\circ} \mathrm{C} / 20$ 
min., a reação foi paralisada com $200 \mu \mathrm{L}$ de $\mathrm{HCL}$ 1,0M, seguido de centrifugação (5000 g/ 5 min. a $\left.4^{\circ} \mathrm{C}\right)$. A absorbância $(600 \mathrm{~nm})$ do sobrenadante foi determinada a $30{ }^{\circ} \mathrm{C}$ e os resultados foram expressos em unidades de absorção/minuto de incubação/ mg de proteína.

A atividade da ß-1,3 glucanase das amostras do ensaio 3.2 foi quantificada colorimetricamente através do uso do "PAHBAH", também empregado em dosagens de carboidratos (Lever, 1972). Laminarina (4mg/mL), foi utilizada como substrato, sendo que esta libera moléculas de glicose sob ação da enzima. A mistura da reação, incubada a $40^{\circ} \mathrm{C}$ por uma hora, continha $50 \mu \mathrm{L}$ do tampão de extração, $200 \mu \mathrm{L}$ da fonte enzimática e $250 \mu \mathrm{L}$ de laminarina.

Após este período de incubação, foi acrescentado 1,5 mL de PAHBAH e incubado novamente ( $100^{\circ} \mathrm{C} / 5 \mathrm{~min}$.), sendo que em seguida as amostras foram resfriadas em gelo e suas absorbâncias lidas a $410 \mathrm{~nm}$, contra o tampão de extração (Abelles \& Foence, 1970). Os resultados foram expressos em $\mu \mathrm{Katal} / \mathrm{mg}$ proteína, de acordo com a metodologia de Bernfeld. (1955).

\subsubsection{Metodologia para a determinação da atividade de peroxidase}

A atividade da peroxidase foi determinada a $30^{\circ} \mathrm{C}$ através do método espectofotométrico direto, pela medida da conversão do guaiacol em tetraguaiacol a $470 \mathrm{~nm}$, como descrito por Hammerschidt et al. (1982). Amostras de tecido vegetal $(0,3 \mathrm{~g})$ foram macerados em almofariz com nitrogênio líquido até a obtenção de um pó fino. A extração das enzimas foi realizada pela adição de $4 \mathrm{~mL}$ de tampão fosfato $0,01 \mathrm{M}\left(\mathrm{pH} \mathrm{6,0)}\right.$ a $4^{\circ} \mathrm{C}$. $\mathrm{O}$ extrato foi centrifugado a $20.000 \mathrm{~g}$ por $25 \mathrm{~min}$ a $4^{\circ} \mathrm{C}$ e o sobrenadante foi coletado com o auxílio de uma pipeta "Pasteur". Em uma cubeta de vidro com capacidade para $3 \mathrm{~mL}$, foram adicionados $2,9 \mathrm{~mL}$ de tampão de reação $(0,153$ $\mu \mathrm{L}$ de peróxido de hidrogênio $0,125 \mu \mathrm{L}$ de guaiacol em $50 \mu \mathrm{L}$ de tampão de 
extração) a 0,1 mL do extrato vegetal (sobrenadante). A reação foi seguida espectofotometricamente pela alteração na absorção a $470 \mathrm{~nm}$. A atividade da peroxidase foi expressa como atividade específica (unidade de absorbância/min/mg de proteína), sendo a determinação de proteínas efetuada de acordo com o método de Bradford (1976), tendo a albumina de soro bovino (BSA) como padrão (Hammerschimidt et al., 1982). 


\section{RESULTADOS E DISCUSSÃO}

4.1 Conteúdo de proteínas e fenóis totais e atividades de $\beta-1,3$ glucanase e quitinase em nove híbridos de milho infectados pelo fitoplasma do enfezamento

Aumento nos níveis protéicos foram constatados em 8 dos 9 híbridos de milho inoculados (Figura 1). Por sua vez, a presença do fitoplasma não provocou aumento no conteúdo protéico somente para o híbrido XLX 520. A discussão destes resultados está contida no ítem 4.2.3. 


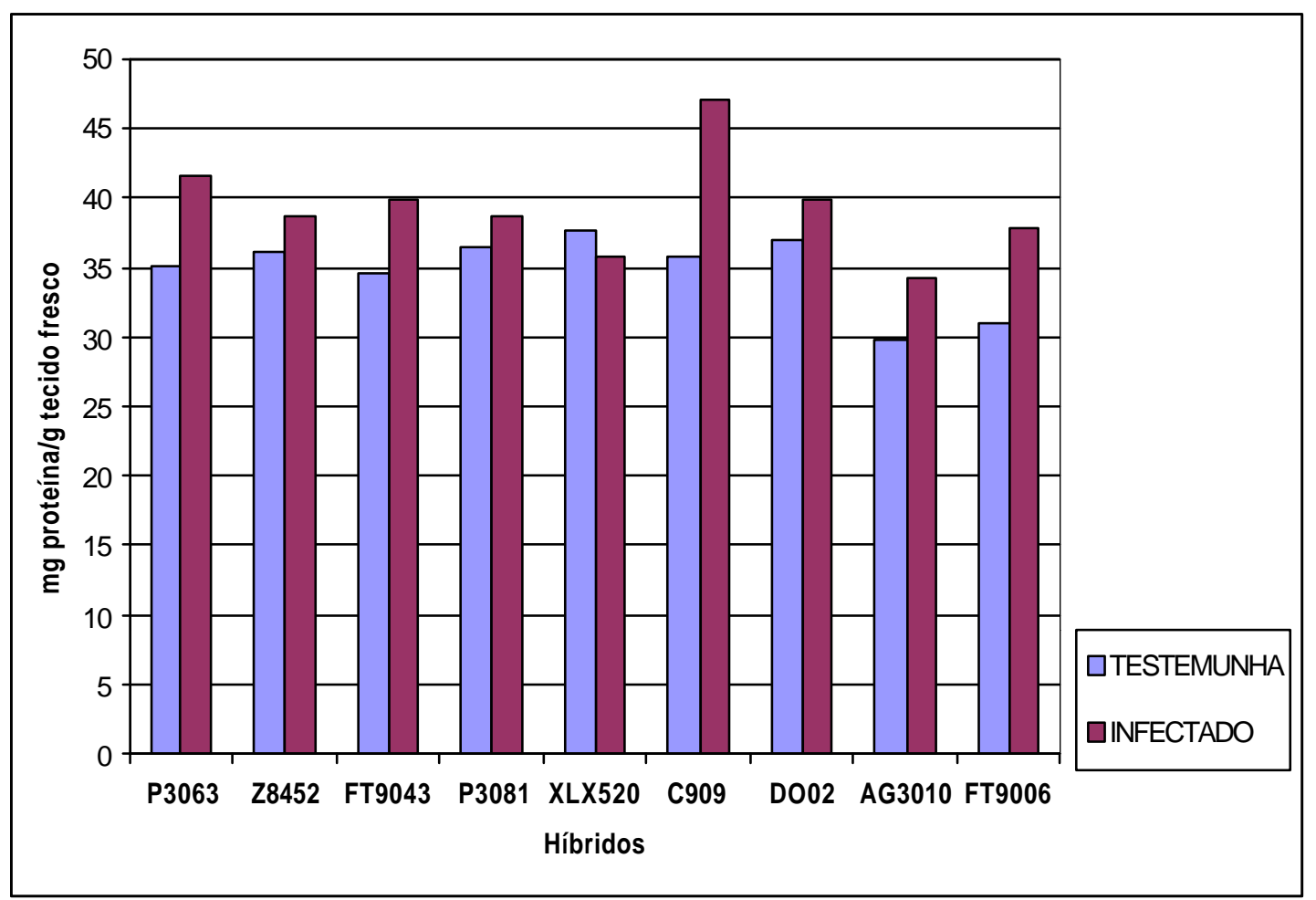

Figura 1- Conteúdo de proteínas totais em nove híbridos comerciais de milho inoculados experimentalmente com o fitoplasma do enfezamento vermelho. Amostras de folhas para análise foram coletadas de plantas com 80 dias após a emergência

Os resultados de análise demonstraram um aumento na atividade da enzima B-1,3 glucanase em todos os híbridos inoculados com o fitoplasma (Figura 2). Os maiores valores de atividade desta enzima foram observados para os híbridos Z 8452, XLX 520, C 909, AG 3010 e FT9006. Discussão sobre estas alterações se encontra no ítem 4.2.6. 


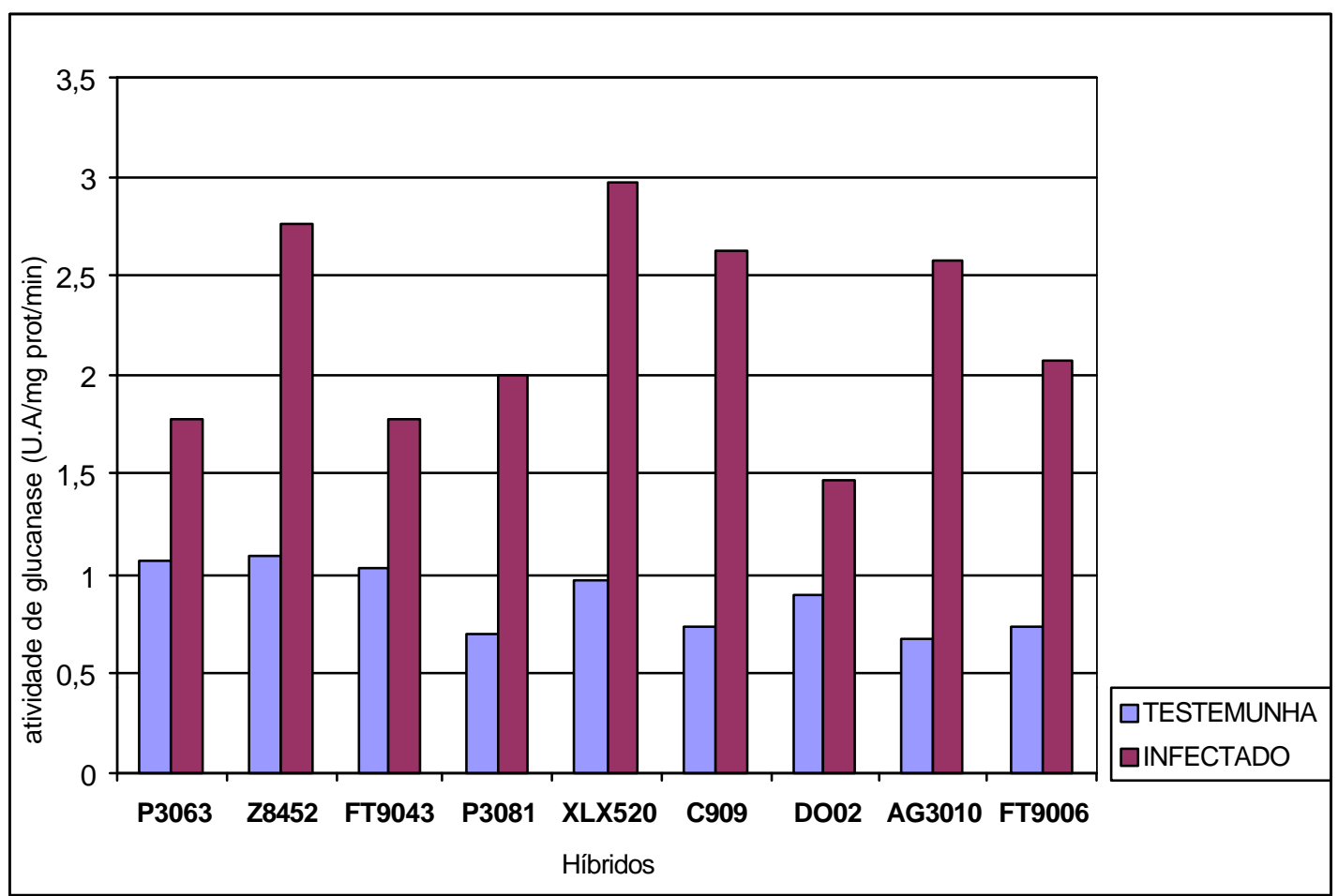

Figura 2- Atividade de ß-1,3 glucanase em nove híbridos comerciais de milho inoculados experimentalmente com o fitoplasma do enfezamento vermelho. Amostras de folhas para análise foram coletadas de plantas com 80 dias após a emergência

Os resultados obtidos para quitinase seguiram o mesmo padrão verificado para $ß-1,3$ glucanase, ou seja, para todos os híbridos inoculados foi constatado um aumento na atividade desta enzima (Figura 3).

A maior atividade de quitinase foi obtida para o híbrido FT 9006, considerado resistente à infecção pelo fitoplasma do enfezamento vermelho, segundo Toffanelli (2001). Essas alterações estão discutidas no item 4.2.6. 


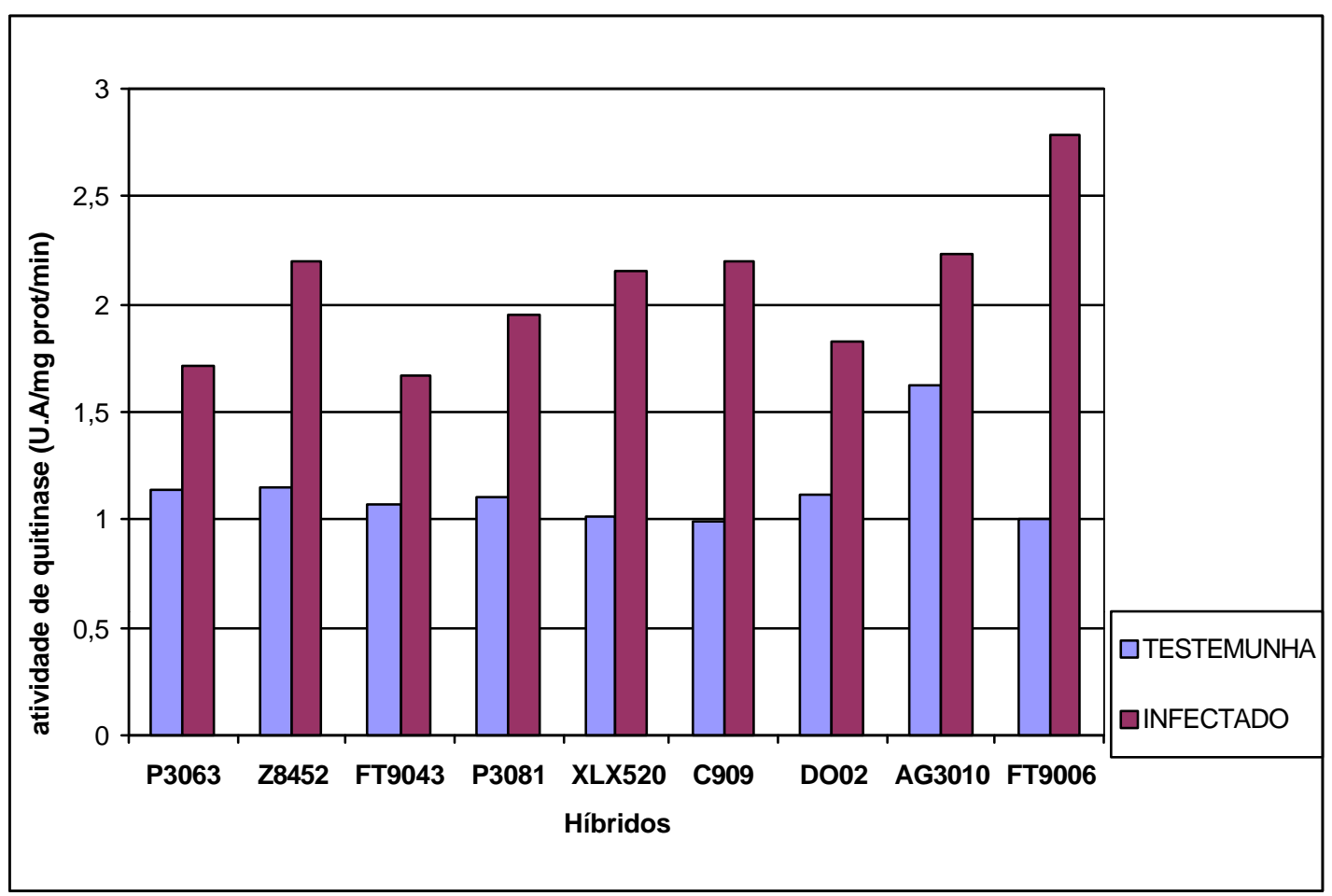

Figura 3- Atividade de quitinase em nove híbridos comerciais de milho inoculados experimentalmente com o fitoplasma do enfezamento vermelho. Amostras de folhas para análise foram coletadas de plantas com 80 dias após a emergência

Quanto aos fenóis totais, foi constatado que os teores destes compostos foram mais elevados em seis híbridos, quando se comparou plantas inoculadas com plantas testemunhas (Figura 4). No entanto, para os híbridos P 3063, C 909 e AG 3010 a presença do fitoplasma nos tecidos provocou redução nos teores de fenóis em comparação com os tecidos sadios. Aspectos relacionados a alterações de compostos fenólicos estão discutidos no ítem 4.2.4. 


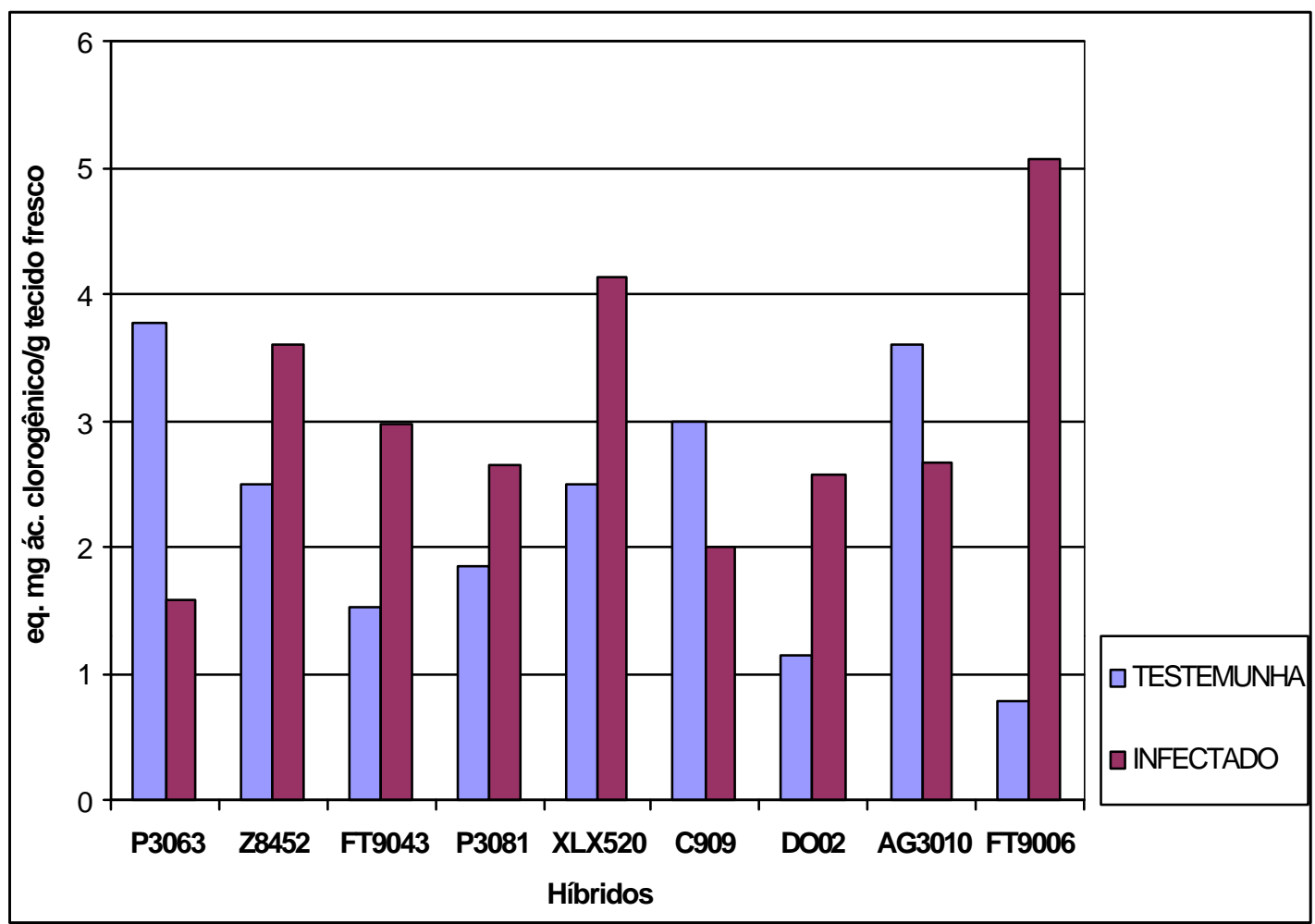

Figura 4- Conteúdo de fenóis totais em nove híbridos comerciais de milho inoculados experimentalmente com o fitoplasma do enfezamento vermelho. Amostras de folhas para análise foram coletadas de plantas com 80 dias após a emergência

Uma visão geral das alterações bioquímicas que ocorreram em plantas inoculadas pertencentes aos nove híbridos de milho está apresentada na Figura 5. Em termos percentuais, considerando-se plantas inoculadas e plantas livres de fitoplasma, as maiores alterações foram observadas para as atividades das enzimas B-1,3 glucanase e quitinase, e, em seguida, fenóis e proteínas totais, respectivamente. 


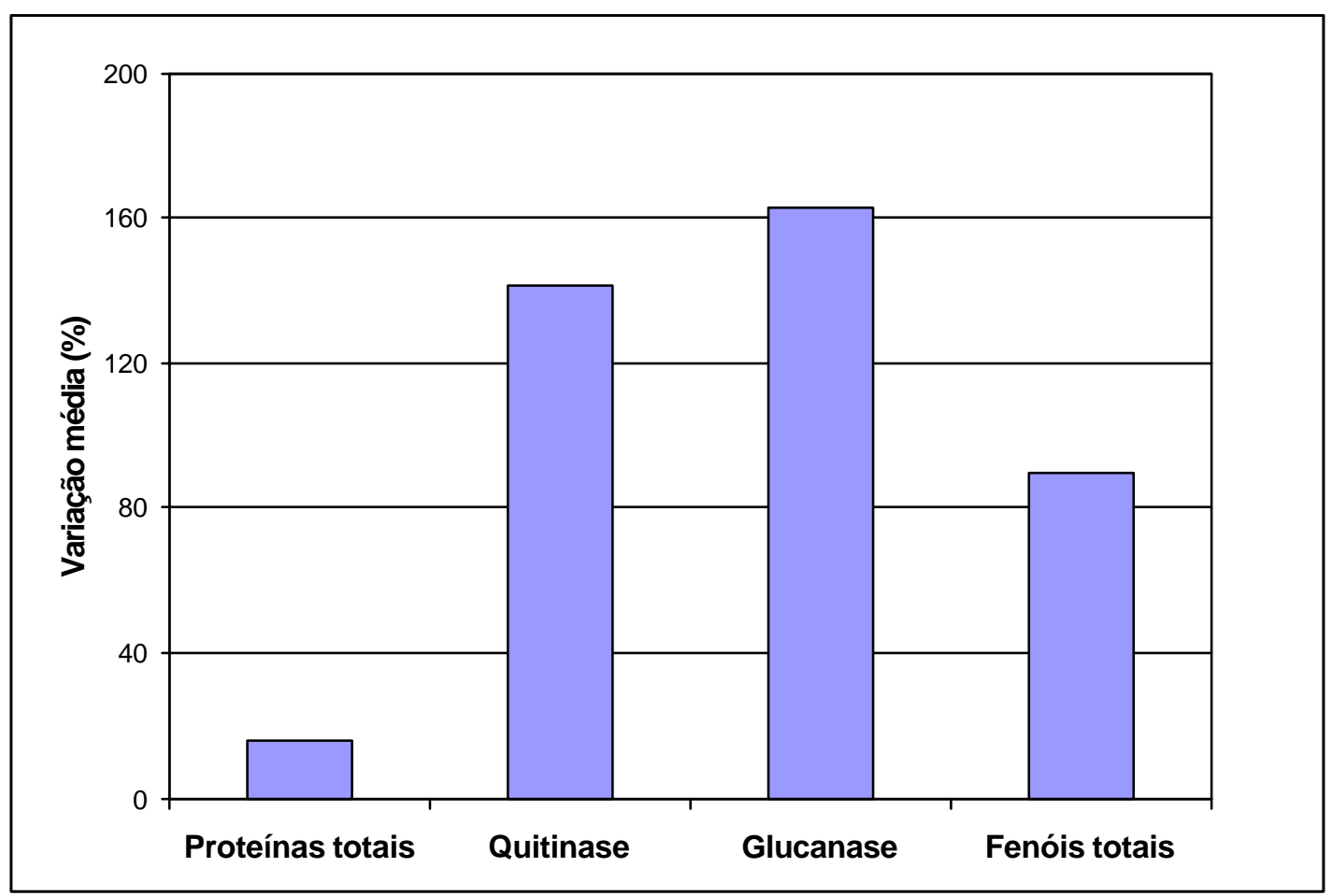

Figura 5- Variação média percentual no conteúdo de proteínas e fenóis totais e nas atividades das enzimas B-1,3 glucanase e quitinase em tecidos de plantas de milho inoculadas com o fitoplasma, em relação æ̀ plantas sadias

As respostas das plantas inoculadas dos nove diferentes híbridos quanto aos teores de proteínas e fenóis totais, das enzimas ß-1,3 glucanase e quitinase aliadas aos diferentes graus de resistência exibidos por estes híbridos, frente à infecção pelo fitoplasma, como descrito por Toffanelli (2001), serviram como referência para a escolha de dois híbridos para realização das demais determinações bioquímicas. Assim, os híbridos XLX 520 e FT 9006 foram considerados como suscetível e resistente, respectivamente. Estes materiais foram utilizados nos ensaios subsequentes visando confirmar os resultados obtidos para os parâmetros já analisados, bem como avaliar novos 
parâmetros bioquímicos relacionados à clorofila, aos açúcares redutores e à enzima peroxidase.

\subsection{Teores de clorofila total, açúcares redutores, proteínas e fenóis totais, peroxidase, $\beta$, 1-3 glucanase e quitinase em dois híbridos de milho infectados pelo fitoplasma do enfezamento vermelho}

As amostras de plantas inoculadas e não-inoculadas foram avaliadas para os diferentes parâmetros bioquímicos aos 0 (material não inoculado), 40, 50, 70 e 80 dias após a inoculação. Esses períodos foram estabelecidos, pois somente a partir dos 40 dias as plantas inoculadas passaram a exibir os sintomas iniciais do enfezamento e o fitoplasma passou a ser detectado através da técnica de PCR.

\subsubsection{Clorofila total}

Os resultados obtidos demonstraram que nos tecidos foliares dos híbridos XLX 520 e FT 9006 inoculados ocorreu redução na quantidade de clorofila. No entanto, essa redução só foi estatisticamente significativa para 0 híbrido XLX 520. Para este híbrido suscetível, tanto nas plantas inoculadas como naquelas não-inoculadas, foi detectado um aumento do conteúdo de clorofila, quando as amostras foram avaliadas aos 40 dias após a inoculação com o fitoplasma. A partir deste período, foi demonstrado que estas substâncias decresceram até aos 80 dias após a inoculação (Figura 6). 


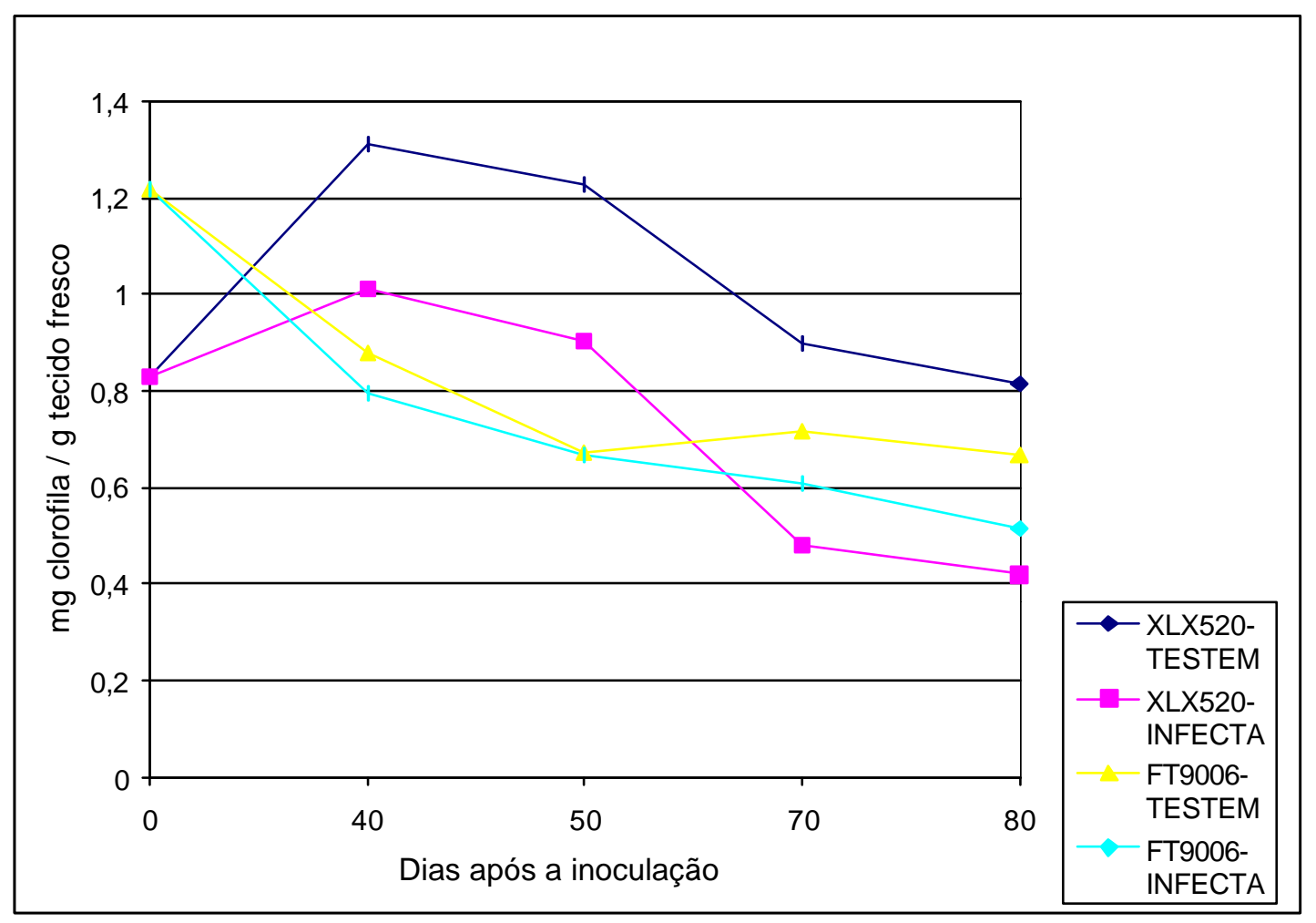

Figura 6- Conteúdo de clorofila total resultante da infecção pelo fitoplasma, em dois híbridos de milho, XLX 520 (suscetível) e FT9006 (resistente). As plântulas de milho foram inoculadas com 10 dias de idade através de 7 cigarrinhas infectivas (Dalbulus maydis). Coeficiente de variação $(C V)$ do ensaio $=18,5$ e desvio padrão $(D P)=0,1550$

Para o híbrido FT 9006 (resistente), foi constatada redução contínua nos níveis de clorofila, ao longo do tempo, tanto para as plantas inoculadas como para as não-inoculadas, nos diferentes períodos de amostragem (Figura 6).

A Figura 9 mostra que plantas inoculadas dos híbridos XLX520 e FT9006 tiveram uma redução média destas substâncias da ordem de 36\% e 10\%, respectivamente, quando comparadas às respectivas testemunhas.

Em geral, plantas de milho infectadas pelo fitoplasma do enfezamento vermelho começam a exibir os primeiros sintomas da doença aos 30 dias após a infecção (Bedendo, 1999). Estes sintomas incluem clorose, seguida de 
avermelhamento do ápice das folhas (Toffanelli, 2001). O sintoma de clorose aparece em decorrência da senescência normal das plantas. Neste trabalho, foi possível notar que a senescência foliar foi acelerada em plantas inoculadas, sendo que os sintomas de clorose foram precocemente observados nas mesmas.

Estudo conduzido por Leon et al. (1996) mostrou que em plantas de coqueiro, infectadas pelo fitoplasma que causa o amarelecimento foliar (LY), ocorreu redução no conteúdo de pigmentos fotossintéticos (clorofila e carotenóides), proteínas específicas e também na taxa fotossintética. Os conteúdos de carotenóides e clorofilas $a$ e $b$ foram reduzidos em $60 \%$ de seus níveis originais e o conteúdo de proteínas em $45 \%$. Assim, estas alterações bioquímicas foram consideradas por estes autores como um dos prováveis mecanismos de patogenicidade deste fitoplasma

Guthrie et al. (2001) ao estudarem plantas de mamão com declínio, doença associada a um fitoplasma, verificaram um significativo decréscimo da fotossíntese, logo após a expressão dos primeiros sintomas da doença. Em poucos dias, pouca atividade fotossintética ocorria e também ficava evidente um permanente fechamento estomatal.

Em relação ao fechamento estomatal, Matteoni (1983) relatou que esta situação pode resultar em aumento da temperatura foliar, podendo levar à perda da capacidade fotossintética, através da redução nos níveis de pigmentos relacionados àfotossíntese.

Embora alterações na taxa fotossintética não tenham sido estudadas neste trabalho, a redução obtida nos níveis de clorofila total provavelmente interfere nos níveis de fotossíntese. Nesse sentido, alguns trabalhos mostram que o decréscimo na taxa fotossintética pode ser atribuído à redução na disponibilidade de $\mathrm{CO}_{2}$, devido ao constante fechamento estomatal, à diminuição da capacidade fotossintética ocasionada pela perda de clorofila ou à inibição da fotossíntese provocada pelo acúmulo de carboidratos nas folhas (Guthrie, 2001). 
O pequeno aumento na quantidade de clorofila total observado para plantas não inoculadas do híbrido FT 9006 dos 50 aos 70 dias não indica necessariamente que houve um aumento da taxa fotossintética. Esta alteração pode ter ocorrido não somente devido àredução dos pigmentos fotossintéticos, como as clorofilas, mas também devido ao fechamento de estômatos. Além disso, deve-se considerar, que pode ter ocorrido erro experimental na amostragem.

Para melhor compreensão do comportamento fotossintético de plantas de milho infectadas pelo fitoplasma, seria necessário abordar outros fatores, como disponibilidade de $\mathrm{CO}_{2}$, condutância estomatal e alteração de outros pigmentos fotossintéticos. No entanto, ficou demonstrado que a interação entre plantas de milho e fitoplasma altera a fisiologia do vegetal, com base no conteúdo de clorofila total, trazendo prejuízos æ̀s plantas, uma vez que a senescência das mesmas foi acelerada.

\subsubsection{Açúcares redutores (carboidratos)}

Quanto ad conteúdo de carboidratos, plantas inoculadas de ambos os híbridos apresentaram valores estatisticamente mais elevados destas substâncias que as plantas não-inoculadas. Considerando apenas plantas nãoinoculadas, ocorreu diferença estatística entre os teores de açúcares para os dois híbridos analisados. No entanto, para plantas inoculadas não houve diferença significativa nos teores destas substâncias entre os híbridos.

Para o híbrido XLX 520, plantas não-inoculadas apresentaram valores crescentes de carboidratos até o período de 70 dias, sendo que aos 80 dias, apresentaram uma pequena redução. As plantas inoculadas mostraram um aumento destes compostos aos 40 dias, sendo que no período decorrido entre os 40 e 50 dias, esses valores foram ligeiramente reduzidos, voltando a aumentar nos períodos seguintes (Figura 7). 


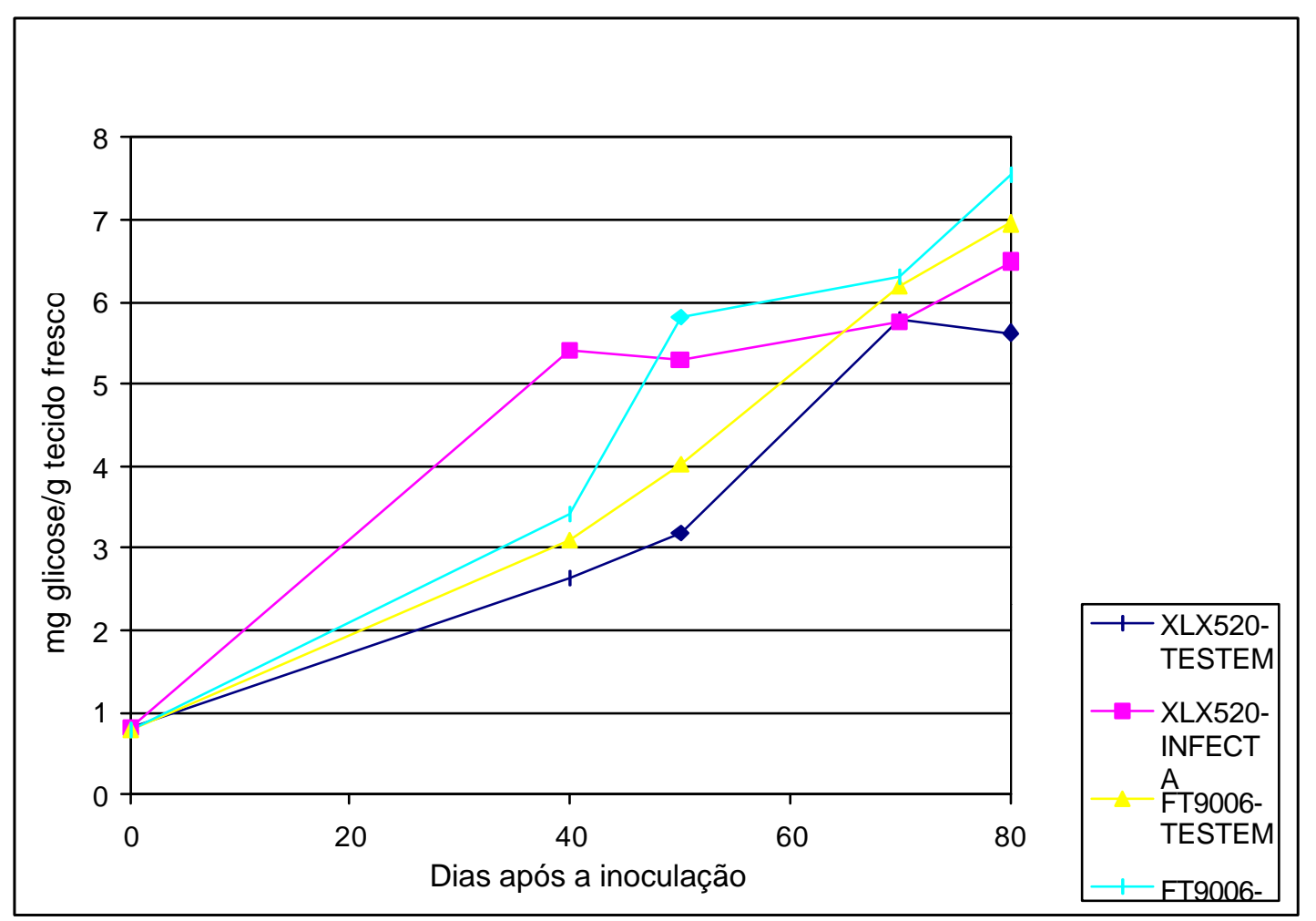

Figura 7- Conteúdo de açúcares redutores resultante da infecção pelo fitoplasma, em dois híbridos de milho, XLX 520 (suscetível) e FT9006 (resistente). As plântulas de milho foram inoculadas com 10 dias de idade através de 7 cigarrinhas infectivas (Dalbulus maydis). Coeficiente de variação (CV) do ensaio $=12,4$ e desvio padrão $(\mathrm{DP})=0,53$

As plantas inoculadas e não-inoculadas do híbrido FT 9006 mostraram valores crescentes de carboidratos durante seu desenvolvimento. As plantas inoculadas deste híbrido, apesar de exibirem valores crescentes destas substâncias, tiveram um padrão distinto daquele obtido para plantas inoculadas do híbrido XLX 520 (Figura 7).

A Figura 9 mostra que plantas de milho inoculadas com fitoplasma têm seus teores de açúcares redutores elevados. No entanto, esse aumento foi 
maior para o híbrido suscetível XLX 520 do que para o híbrido resistente FT 9006.

O aumento de carboidratos pode explicar abuns dos sintomas observados após a infecção pelo fitoplasma. Plantas de milho inoculadas, mostraram inicialmente clorose nos bordos das folhas, seguida de um avermelhamento dos ápices das folhas mais velhas. Essa sintomatologia apresentada pelas folhas mais velhas pode ser resultado de um acúmulo de carboidratos, tomando-se por base o trabalho de Scneider (1977). Assim sendo, para o híbrido XLX 520, mais suscetível, o qual desenvolveu uma sintomatologia mais acentuada, já era esperado que o mesmo apresentasse um maior aumento do nível de carboidratos em plantas inoculadas. Quanto ao híbrido FT 9006, considerado resistente e com menor intensidade de sintomas, este aumento ocorreu em menores proporções.

O acúmulo de carboidratos em folhas de plantas infectadas por fitoplasmas vem sendo relatado por diversos autores. Guthrie et al. (2001) atribuem este acúmulo a um bloqueio causado no floema pelo patógeno, através da sua própria presença ou ainda através da indução do hospedeiro em produzir metabólitos tóxicos. Geralmente estes carboidratos se acumulam nas folhas e diminuem no caule e raízes de plantas infectadas, sendo que este processo ocorre, normalmente concomitante ou ligeiramente após uma redução na taxa fotossintética das plantas (com provável redução de pigmentos relacionados à fotossíntese). Este tipo de relato, vem de encontro aos resultados obtidos no presente trabalho, pois ao mesmo tempo em que as plantas inoculadas tiveram seus teores de açúcares elevados, apresentaram também redução em seus teores de clorofila total e possivelmente redução nas taxas de fotossíntese.

Ao estudarem plantas de coqueiro infectadas pelo fitoplasma do LY, Maust et al. (2003) também verificaram que a concentração de amido e açúcar aumentou em folhas, tanto do ápice como do meio das plantas e, decresceu rapidamente nas raízes. Esses autores inferiram que embora a fotossíntese e a 
concentração de carboidratos tenha diminuído nas raízes, a concentração de carboidratos aumentou nas folhas, sugerindo inibição no transporte de açúcar através dos vasos do floema.

Os resultados obtidos neste trabalho são concordantes com aqueles obtidos por Lepka et al. (1999). Esses autores ao analisarem o efeito da infecção pelo fitoplasma sobre a concentração e translocação de carboidratos solúveis e amido em plantas de vinca e de fumo concluíram que a translocação foi severamente comprometida, uma vez que essas substâncias, em plantas doentes, foram muito mais elevadas em tecidos de folhas do que nas raízes, quando comparadas às plantas sadias. Com base no trabalho de Lepka e colaboradores, pode-se inferir que o equilíbrio entre a área de produção e de consumo pode ser comprometido pelo fitoplasma, com aumento do afluxo de carboidratos para áreas infectadas. Em outras palavras, a exportação de nutrientes das folhas para o resto da planta fica prejudicada.

O aumento do teor de carboidratos em plantas infectadas por fitopatógenos tem sido algumas vezes atribuído a degradação de componentes da parede celular das plantas, componentes estes que incluem açúcares (monossacarídeos) e que podem ser utilizados diretamente por alguns patógenos (Pascholati, 1995). O amido, um polímero da glicose, constitui-se no principal polissacarídeo de reserva das células vegetais, sendo que alguns patógenos também são capazes de produzir amilases, as quais degradam esse polímero em moléculas de glicose, prontamente utilizáveis nas atividades metabólicas desses microorganismos. Assim, seria interessante investigar a maneira pela qual os fitoplasmas retiram das plantas os nutrientes necessários para sua sobrevivência e crescimento.

\subsubsection{Proteínas totais}

Os resultados das análises do conteúdo de proteínas totais para os diferentes estádios de desenvolvimento de ambos os híbridos estão 
apresentados na Figura 8. As plantas que foram inoculadas apresentaram um aumento significativo na quantidade destas substâncias quando comparadas com as testemunhas. Os maiores valores de proteínas foram observados para o híbrido FT 9006, tanto para as plantas inoculadas como para as nãoinoculadas. De modo geral, o teor de proteínas teve um incremento ao longo do ciclo de desenvolvimento das plantas, seguindo um mesmo padrão de alteração.

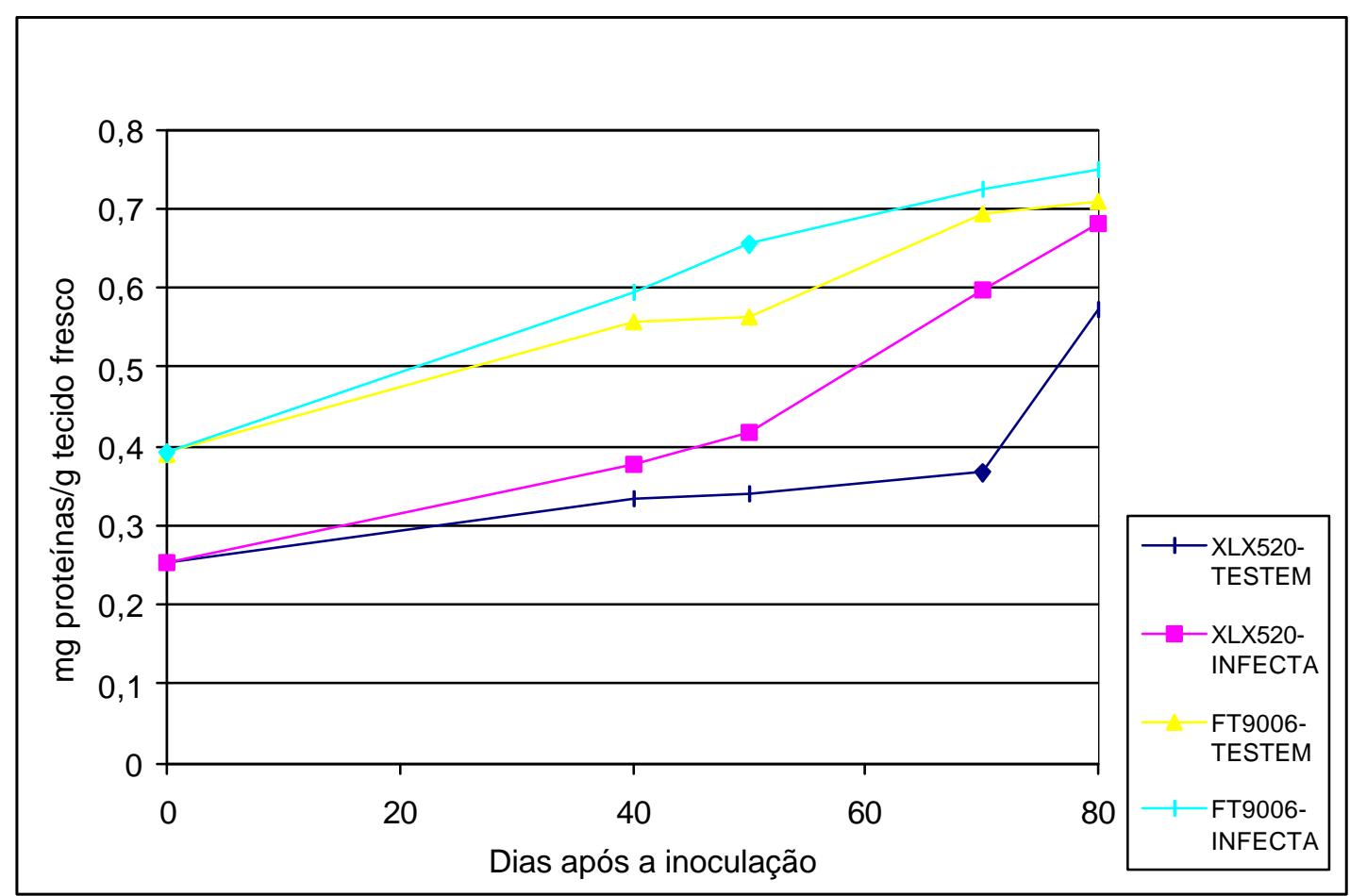

Figura 8- Conteúdo de proteínas totais resultante da infecção pelo fitoplasma, em dois híbridos de milho, XLX 520 (suscetível) e FT9006 (resistente). As plântulas de milho foram inoculadas com 10 dias de idade através de 7 cigarrinhas infectivas (Dalbulus maydis). Coeficiente de variação (CV) do ensaio = 14,1 e desvio padrão (DP) $=0,07$ 
Uma visão geral dos resultados obtidos nas análises de clorofila total, açúcares redutores e proteínas totais em relação a plantas inoculadas e não inoculadas dos dois híbridos estudados está apresentada na Figura 9. Observase que a presença do fitoplasma nos tecidos vegetais provocou um aumento nos teores de carboidratos e de proteínas totais, porém causou redução no conteúdo de clorofila total.

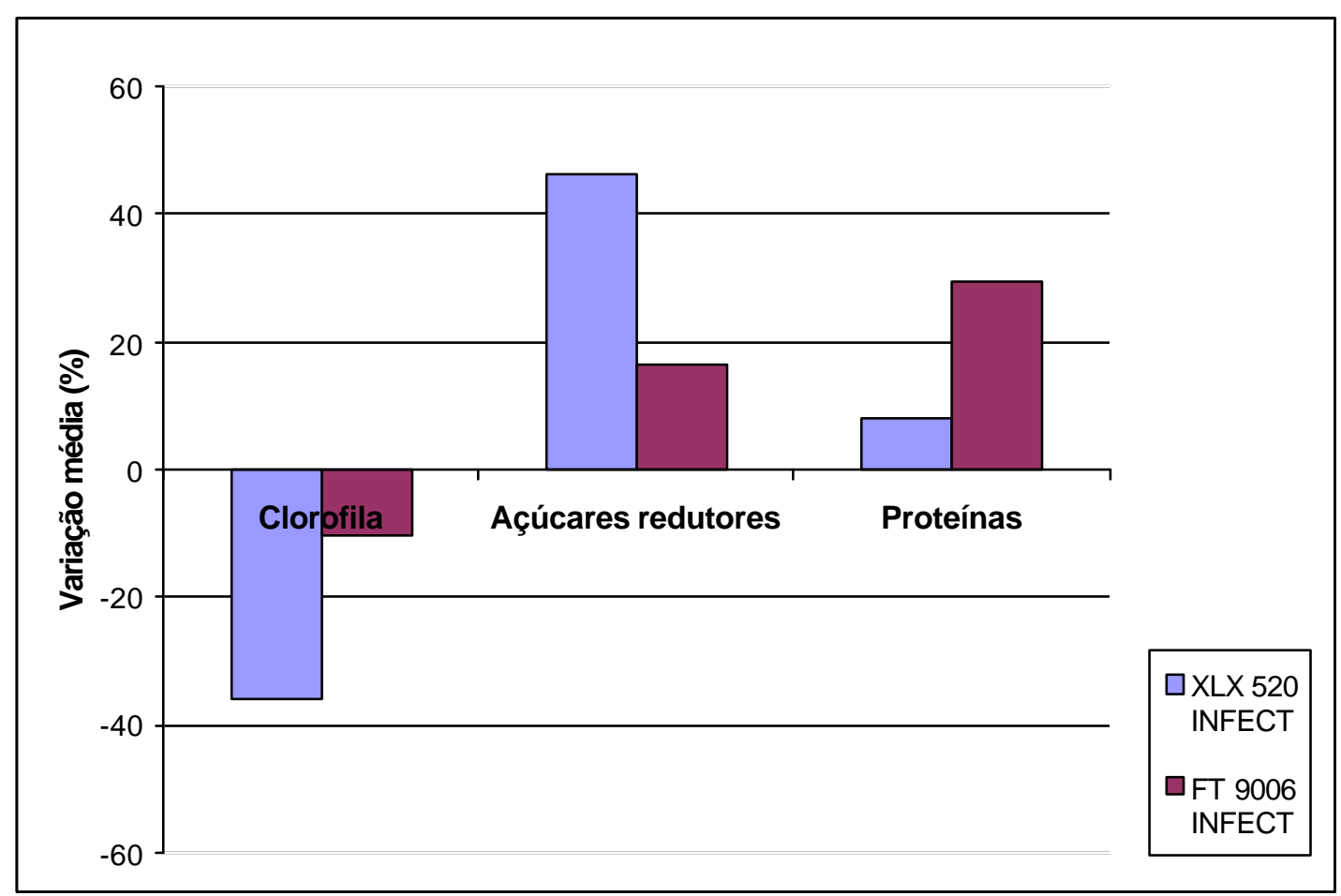

Figura 9- Variação média percentual no conteúdo de clorofila total, açúcares redutores e proteínas totais observada nos tecidos de folhas de plantas de milho inoculadas com fitoplasma, em relação æ̀ plantas sadias, em dois híbridos de milho, XLX 520 (suscetível) e FT 9006 (resistente)

O híbrido FT 9006 (resistente) apresentou quantidades superiores de proteínas totais quando comparado ao híbrido XLX 520 (suscetível). Isto pode ser provavelmente atribuído à genética do material vegetal, uma vez que 
mesmo as plantas não-inoculadas do híbrido resistente apresentaram conteúdo protéico superior àqueles verificados para o híbrido XLX 520.

A constatação de que plantas inoculadas de ambos os híbridos apresentaram valores mais elevados de proteínas do que plantas testemunhas encontra respaldo na literatura. Em geral, plantas infectadas por fitopatógenos sofrem um aumento considerável quanto ao conteúdo de proteínas. O aumento pode ser explicado como sendo proveniente da ação conjunta dos organismos envolvidos na interação patógeno-hospedeiro. A planta, de um lado, procura ativar seus mecanismos de defesa para evitar o estabelecimento de relações parasitárias e o patógeno, por outro lado, tenta anular os efeitos inibitórios gerados pelo hospedeiro. Nas chamadas ilhas verdes, representadas pelas áreas em torno dos sítios de infecção, é comum ocorrer acúmulo de proteínas, enquanto que nas áreas cloróticas observa-se um declínio (Pascholati \& Leite, 1995). Villanueva, citado por Leon et al. (1996), observou um decréscimo de polipeptídeos em folhas de palmeiras com amarelecimento letal (LY). Um destes polipeptídeos, segundo aquele autor, poderia ser uma grande subunidade da ribulose bifosfato carboxilase (rubisco), uma enzima chave do ciclo na fixação de $\mathrm{CO} 2$ e que constitui $50 \%$ ou mais do total de proteínas solúveis da folha. Assim, apesar do aumento do conteúdo protéico nos tecidos doentes, individualmente algumas proteínas podem sofrer diminuição na sua concentração, como foi verificado para o caso da rubisco.

Dentre algumas proteínas relacionadas à defesa, produzidas pelo hospedeiro, encontram-se as proteínas-RP, dentre as quais pode-se incluir $\beta$ 1,3 glucanases, quitinases e peroxidases. O aumento dessas proteínas-RP, em plantas infectadas pelo fitoplasma, podem ter contribuído para o aumento nos níveis de proteínas totais nessas plantas.

Em Inhas gerais, à medida que plantas são infectadas pelo fitoplasma, este multiplica-se progressivamente nos vasos do floema. Com isso, o aumento nos níveis protéicos, observado ao longo do ciclo de desenvolvimento destas plantas, poderia ser atribuído ao aumento da concentração de células do 
patógeno nos vasos do floema, além do processo natural de senescência das plantas. Isto pode justificar o maior teor de proteínas totais observado em plantas inoculadas do híbrido XLX 520, pois sendo mais suscetível poderia favorecer a multiplicação do fitoplasma em seus tecidos.

Pesquisas conduzidas por Lepka et al. (1999) mostraram que a concentração de aminoácidos não foi alterada em plantas de vinca e de fumo infectadas pelo fitoplasma. Esses resultados estão em desacordo com aqueles obtidos em nosso estudo, uma vez que aqui a concentração de proteínas em tecidos infectados foi aumentada. Com base neste estudo, não poderíamos atribuir o maior aumento de proteínas totais, em tecidos infectados, ao bloqueio no transporte de seiva elaborada pelo floema. No entanto, está claro que alteração no conteúdo de aminoácidos, como o que foi descrito por Lepka et al (1999), não reflete como um todo a alteração nos níveis de proteínas totais, pois os aminoácidos representam apenas uma fração das proteínas constituintes das plantas, sendo assim necessário estudos mais detalhados.

\subsubsection{Fenóis totais}

Plantas inoculadas de ambos os híbridos apresentaram teores de fenóis significativamente superiores àqueles obtidos para as plantas não-inoculadas (Figura 10). Os compostos fenólicos tiverem suas concentrações aumentadas com a idade das plantas, independentemente do híbrido analisado e se estes híbridos foram ou não inoculados. 


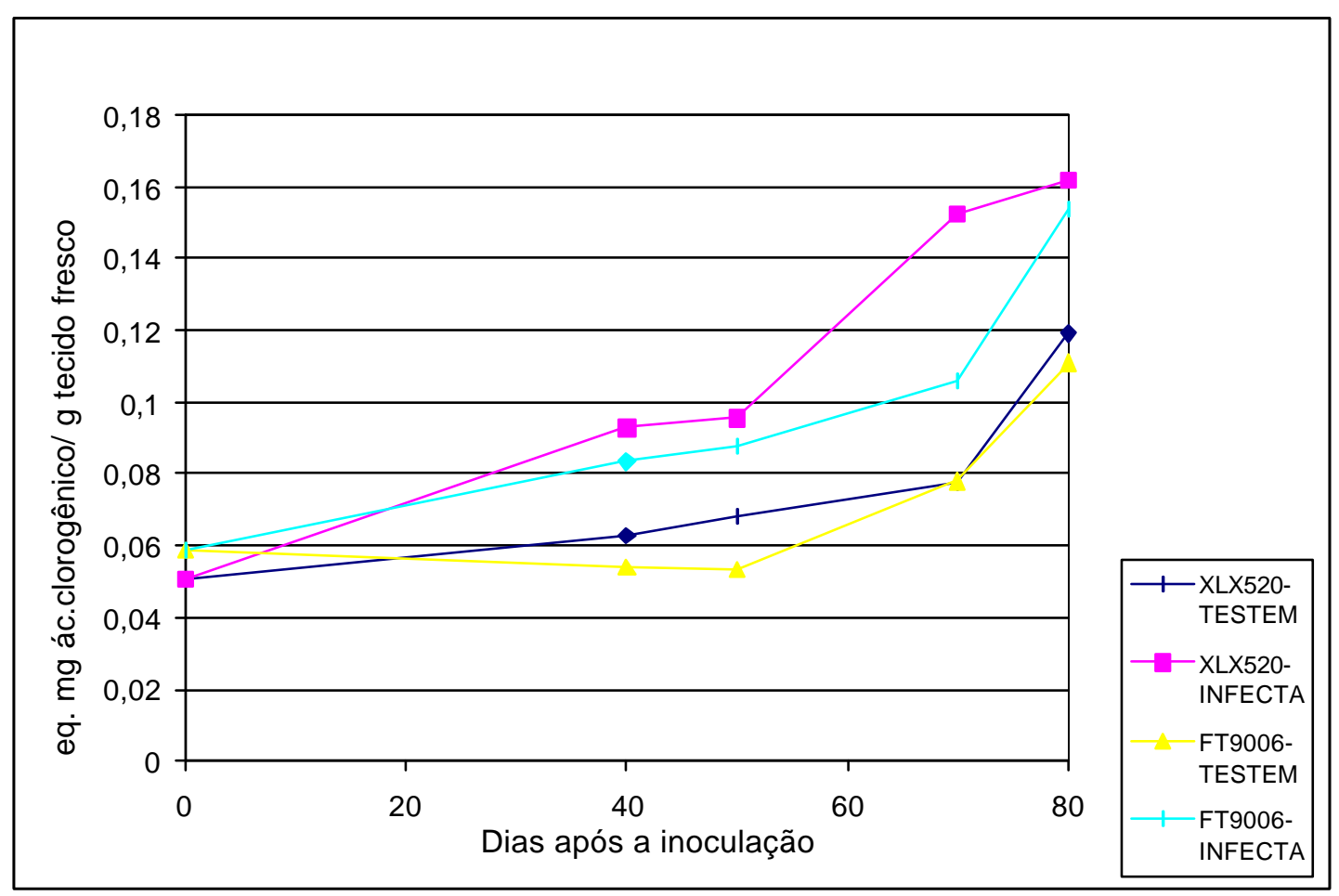

Figura 10- Conteúdo de fenóis totais resultante da infecção pelo fitoplasma, em dois híbridos de milho, XLX 520 (suscetível) e FT9006 (resistente). As plântulas de milho foram inoculadas com 10 dias de idade através de 7 cigarrinhas infectivas (Dalbulus maydis). Coeficiente de variação $(\mathrm{CV})$ do ensaio $=18,0$ e desvio padrão $(\mathrm{DP})=0,01$

A presença de fitoplasma nos tecidos de milho promoveu um aumento no nível de compostos fenólicos da ordem de 57,5\% para as plantas pertencentes ao híbrido suscetível XLX520 ( Figura 11). Para o caso do híbrido FT 9006, resistente, um aumento de 47,2\% na concentração de fenóis foi verificada em plantas inoculadas, quando comparadas com as testemunhas. 


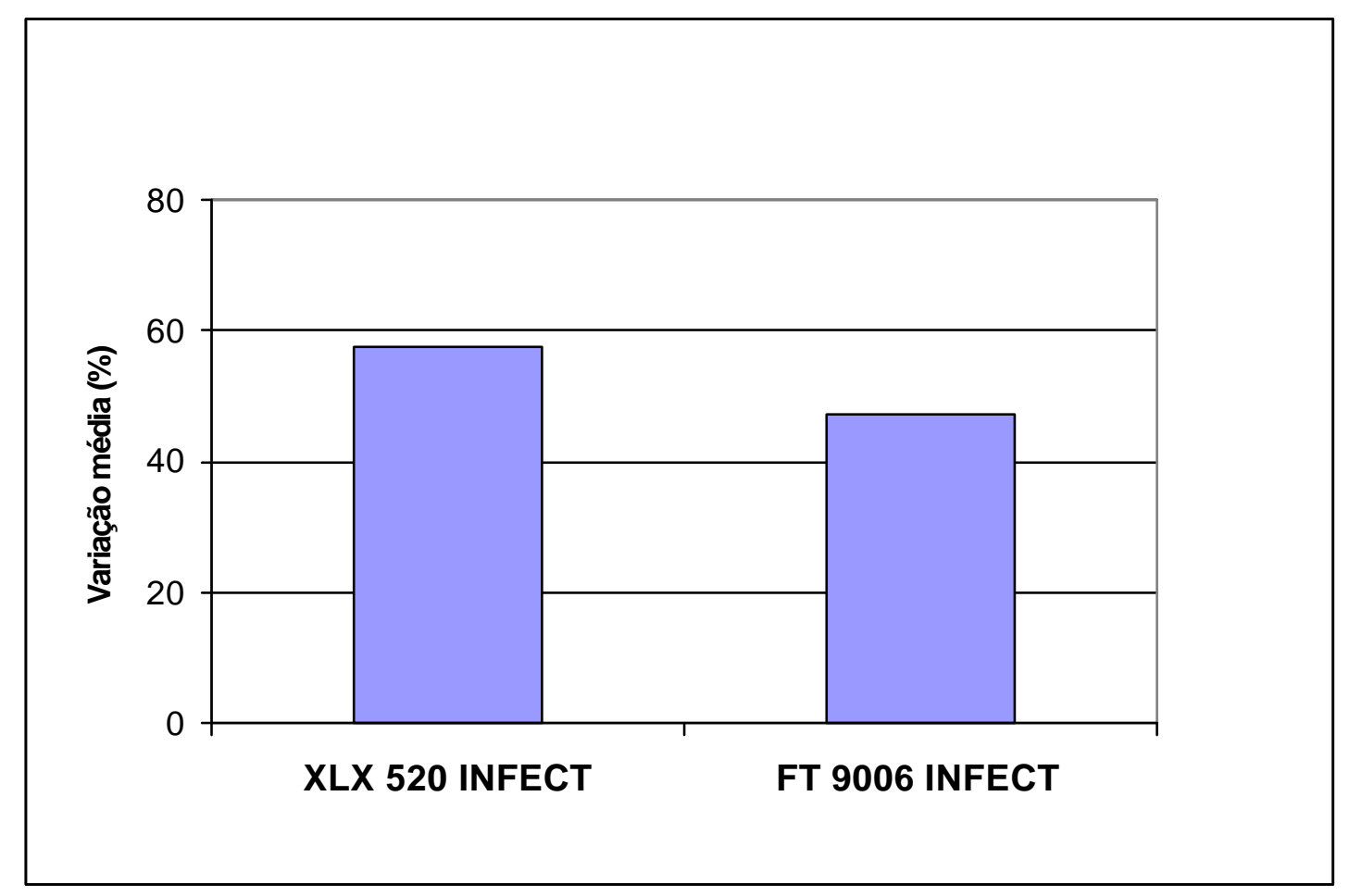

Figura 11- Variação média percentual no conteúdo de fenóis totais em tecidos de folhas de plantas de milho inoculadas com fitoplasma, em relação às plantas sadias, em dois híbridos, XLX 520 (suscetível) e FT 9006 (resistente)

Plantas inoculadas dos dois híbridos tiveram seu metabolismo fenólico alterado. Sabe-se que os compostos fenólicos fazem parte de um arsenal de substâncias que podem estar diretamente relacionados com a defesa das plantas, podendo contribuir para o isolamento de um patógeno, ainda no sítio de infecção. $O$ acúmulo de fenóis em tecidos vegetais depende do patossistema, do nível de resistência do hospedeiro e, no caso de resistência induzida, do indutor (Nicholson \& Hammerschmidt, 1992). Por exemplo, a resistência ao fungo Cochliobolus heterostrophus em plantas de milho portadoras do gene $\mathrm{rhm}$ envolve, quase que exclusivamente, fenilpropanóides (Nicholson \& Hammerschmidt 1992). Plantas de milho e sorgo resistentes a 
Peronosclerospora sorghi apresentam não só diferenças quantitativas, mas também qualitativas em seus compostos fenólicos (Anwar et al., 1995).

Musetti et al. (2000) constataram um significativo aumento na quantidade de cutina, suberina e tanino (substância envolvida na lignificação) em plantas de maçã e ameixa infectadas por fitoplasma. Análise de polifenóis totais confirmaram um aumento destas substâncias em tecidos infectados, especialmente para plantas de ameixa. Estes autores sugeriram que estes metabólitos poderiam exercer um papel importante na defesa das plantas infectadas. Assim, segundo estes autores, um aumento na lignificação poderia estar relacionado com a tentativa das plantas em restringir a multiplicação de fitoplasmas nos vasos do floema.

Um dos sintomas típicos provocados pelo fitoplasma em plantas de milho se caracteriza pelo intenso avermelhamento foliar. Este avermelhamento, possivelmente se deve ao acúmulo de antocianinas nas folhas (Nicholson \& Hammerschmidt, 1992). As antocianinas fazem parte dos compostos fenólicos e assim o aumento de fenóis totais que foi verificado em plantas infectadas, poderia estar relacionado com o aumento destas substâncias. Neste sentido, a resistência a Helminthosporium carbonum em milho foi caracterizada por um intenso acúmulo de antocianinas (não fungitóxicas, mas originárias de precursores fungitóxicos) ao redor dos sítios de infecção, e a resposta suscetível foi caracterizada pela prevenção da síntese de antocianinas ao redor dos sítios de infecção. Quando o fungo Helminthosporium maydis foi inoculado, o mesmo preveniu o acúmulo de antocianinas e fez com que as plantas de milho ficassem suscetíveis à $H$. carbonum (Pascholati \& Nicholson, 1983; Nicholson \& Hammerschmidt, 1992).

Couture et al. (1973) relataram que a síntese de fenóis totais em milho foi incrementada após a inoculação de plantas isogênicas suscetíveis $(h t)$ e resistentes $(H t)$ a $E$. turcicum, sendo que 10 dias após a inoculação os níveis de fenóis totais eram maiores no material resistente. Hammerschmidt \& Nicholson (1977) diferenciaram materiais de milho resistente e suscetível a Colletotrichum 
graminicola com base no conteúdo de fenóis totais, havendo uma correlação entre a restrição do desenvolvimento da lesão e acúmulo desses compostos. Resultados destes trabalhos estão em desacordo com aqueles obtidos em nosso estudo, pois aqui, plantas do material suscetível foram as que apresentaram maiores teores de fenóis totais.

No presente trabalho foram analisadas apenas alterações quantitativas de fenóis. No entanto, trabalhos em que foi avaliada a participação de fenóis na resposta de defesa mostraram que alterações qualitativas e quantitativas ocorreram no perfil de fenóis (Lo et al., 1999). Para um melhor entendimento do comportamento de fenóis em plantas infectadas por fitoplasma seria necessária uma avaliação qualitativa dos fenóis, seja por cromatografia em camada fina (TLC) ou cromatografia líquida (H.P.L.C.).

\subsubsection{Peroxidase}

Os resultados obtidos para peroxidase demonstraram a ocorrência de diferenças entre os níveis desta enzima de plantas inoculadas e plantas nãoinoculadas (Figura 12). A análise destes resultados revelou que plantas inoculadas e não-inoculadas dos dois híbridos apresentaram um máximo de atividade enzimática no período compreendido entre 40 e 50 dias após a inoculação. A partir dos 50 dias, a atividade da peroxidase passou a ser reduzida até o final do período de avaliação. Plantas inoculadas dos dois híbridos, apresentaram atividade de peroxidase significativamente maior do que as plantas não-inoculadas. 


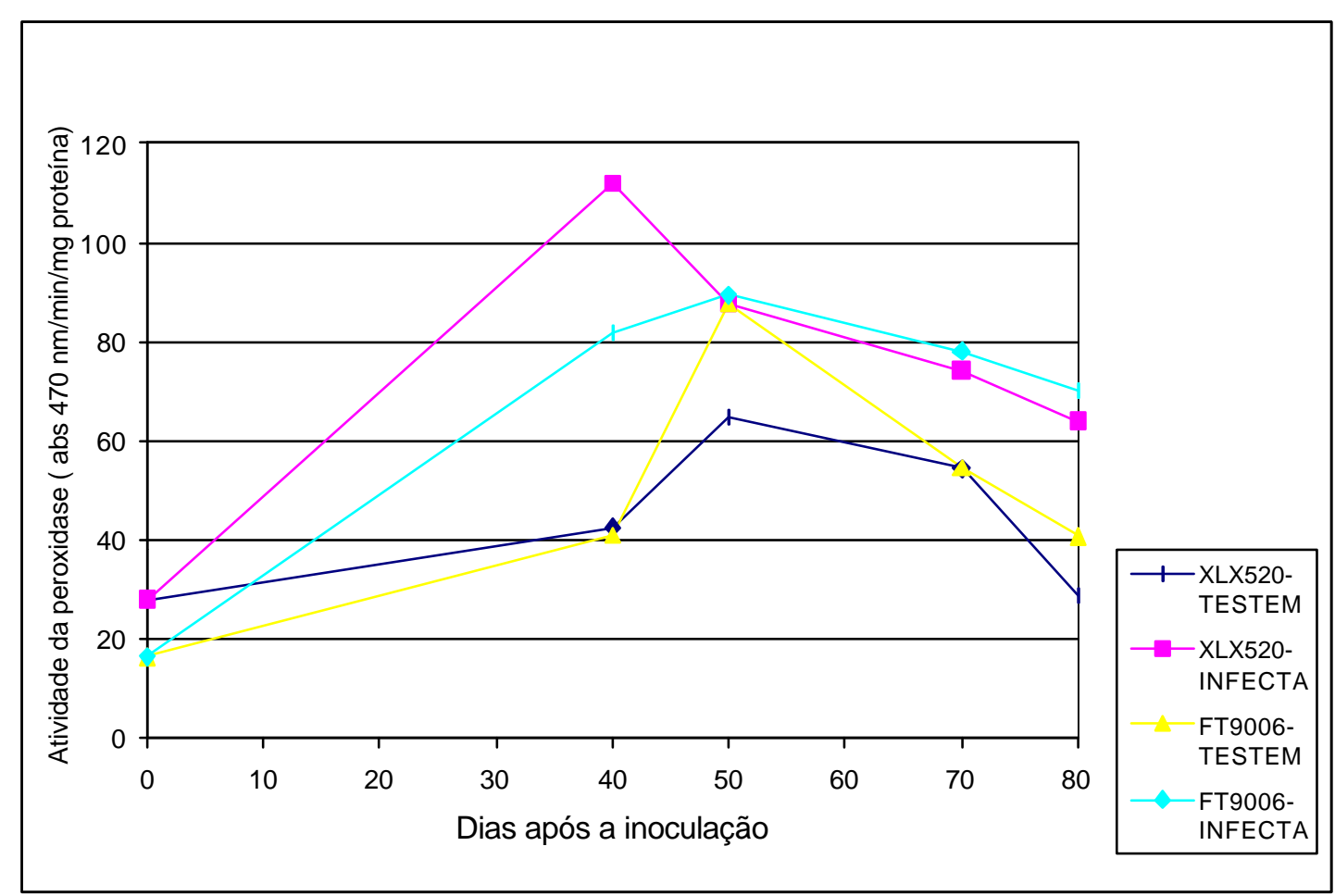

Figura 12- Atividade de peroxidade resultante da infecção pelo fitoplasma, em dois híbridos de milho, XLX 520 (suscetível) e FT9006 (resistente). As plântulas de milho foram inoculadas com 10 dias de idade através de 7 cigarrinhas infectivas (Dalbulus maydis). Coeficiente de variação do ensaio $C V=14,1$ e desvio Padrão $(D P)=8,2$

Plantas inoculadas do híbrido suscetível chegaram a apresentar índice de atividade enzimática $89 \%$ maior do que plantas testemunhas (Figura 15). Valores mais baixos que estes foram obtidos para plantas infectadas do híbrido FT 9006, nas quais a atividade da peroxidase foi $54 \%$ maior do que nas plantas livres de fitoplasma (Figura 15).

A atividade de peroxidase pode estar relacionada à resposta de defesa das plantas, sendo esta uma enzima chave na expressão de resistência para muitas interações patógeno-hospedeiro (Leherer, 1969). Essa enzima atua na oxidação de compostos fenólicos que se acumulam em resposta à infecção, 
atua também na síntese de lignina e na biossíntese do hormônio vegetal etileno (Asada, 1992). Sua atividade pode ser alterada em função da resistência ou suscetibilidade de diferentes hospedeiros na presença de diferentes patógenos (Asada, 1992). Os resultados obtidos neste trabalho mostraram altos níveis da atividade de peroxidase em plantas inoculadas dos híbridos.

Logo após a infecção pelo fitoplasma, plantas de ambos os híbridos aumentaram a atividade da peroxidase, sendo este aumento mais evidente para as plantas do híbrido suscetível. No entanto, este aumento na atividade enzimática não é suficiente para se afirmar que houve ativação dos mecanismos de defesa da planta, já que este aumento não foi capaz de reduzir a intensidade de sintomas exibida pelas plantas. Isto foi observado especialmente para as plantas do híbrido suscetível, as quais apresentaram sintomas evidentes já aos 30 dias após a inoculação. Esses resultados estão em desacordo com aqueles obtidos por Shimoni et al (1991), os quais mostraram que após a infecção de plantas de milho com Exserohilum turcicum, a atividade de peroxidase aumentou mais rapidamente em cultivares de milho resistentes, do que em suscetíveis, sendo que as plantas do cultivar resistente apresentaram sintomas mais tardios e menos intensos.

Normalmente estas enzimas atuam mais como indicadoras do início da evolução da resposta de resistência, do que como elementos destinados à exercer a defesa (Asada, 1992). Embora as peroxidases não possam ser utilizadas como marcadores de resistência bioquímicos, pelo menos neste trabalho, a alteração na sua atividade é um indício de metabolismo alterado.

Muitos trabalhos ao tentarem demonstrar a atividade de peroxidase como marcador de resistência bioquímico, utilizam como ferramenta os diferentes padrões de isoperoxidases obtidos em cultivares resistentes e suscetíveis, já que muitas vezes padrões distintos são obtidos. Shimoni et al (1996) demonstraram que algumas izoenzimas de peroxidase e B-1,3 glucanases estavam correlacionadas com a resistência à E. turcicum, sendo que padrões 
distintos de bandas de isoperoxidases e ß-1,3 glucanases foram encontrados em isolinhas suscetíveis e resistentes.

No presente trabalho, avaliourse apenas alteração quantitativa de peroxidase. Para tentar estabelecer o envolvimento desta enzima no mecanismo de resistência de plantas de milho ao fitoplasma, seria interessante avaliar o perfil eletroforético das diferentes izoenzimas de peroxidase em cultivares resistentes e suscetíveis, uma vez que diferentes isoformas, provavelmente estejam relacionadas a diferentes funções (Shimoni et al., 1996).

\subsection{6 ß-1,3-glucanase e quitinase}

Os níveis de ß-1,3 glucanase presentes em plantas inoculadas do híbrido XLX 520 não diferiram significativamente dos níveis encontrados em plantas inoculadas do híbrido resistente FT 9006 (Figura13). A análise desta enzima em tecidos de plantas inoculadas e não inoculadas com o fitoplasma demonstrou que a atividade desta enzima foi estatisticamente maior nas plantas inoculadas, dos dois híbridos (Figura 13).

Plantas inoculadas do híbrido XLX 520 apresentaram níveis de quitinase significativamente superiores àqueles obtidos em plantas inoculadas do híbrido FT 9006 (Figura 14). Plantas inoculadas dos dois híbridos apresentaram níveis significativamente superiores na atividade desta enzima quando comparados æ̀ suas respectivas testemunhas. 


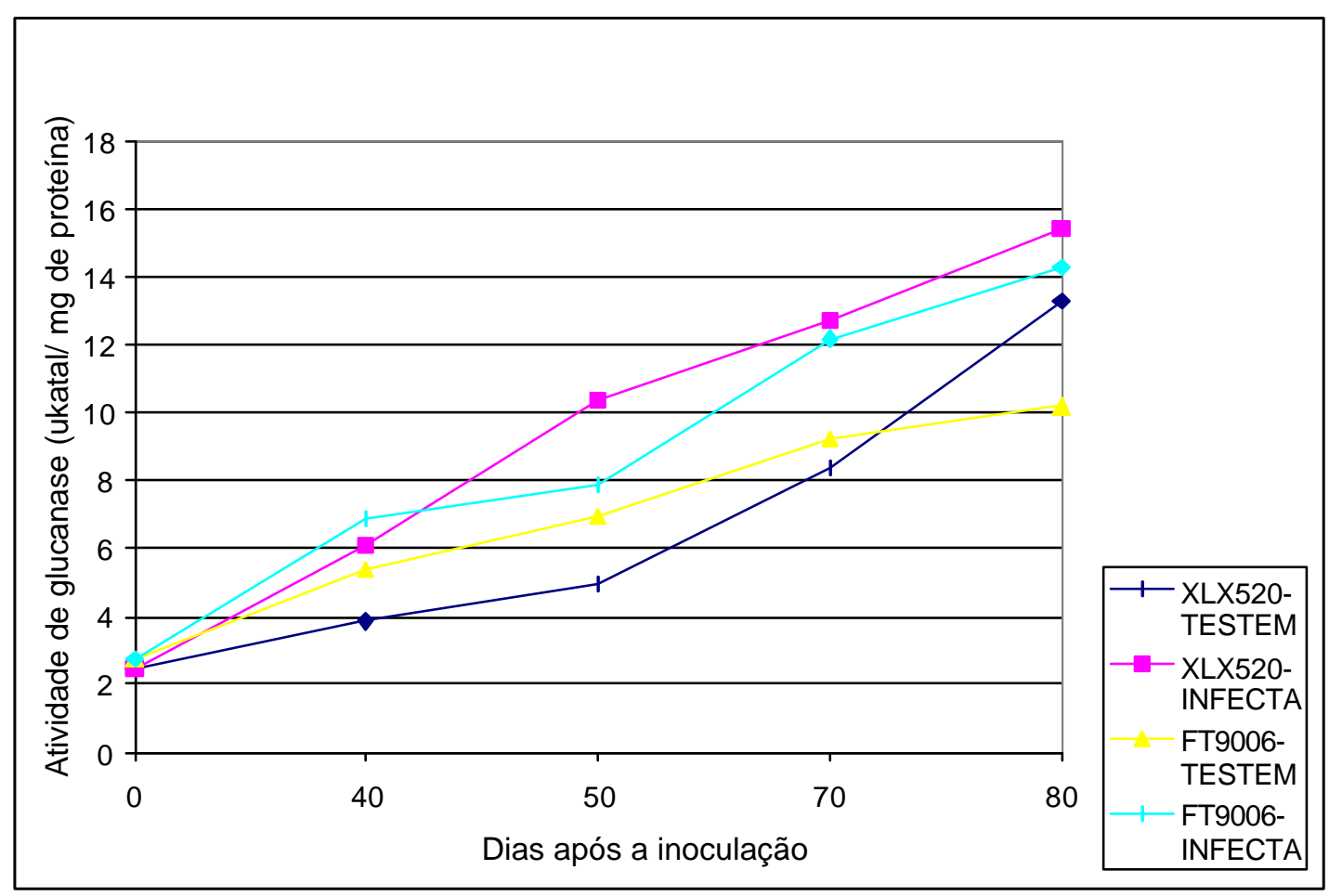

Figura 13- Atividade de ß-1,3 glucanase resultante da infecção pelo fitoplasma, em dois híbridos de milho, XLX 520 (suscetível) e FT9006 (resistente). As plântulas de milho foram inoculadas com 10 dias de idade através de 7 cigarrinhas infectivas (Dalbulus maydis). Coeficiente de variação do ensaio $(\mathrm{CV})=18,9$ e desvio padrão $(\mathrm{DP})=1,5$

A atividade da $B-1,3$ glucanase mostrou valores crescentes com a idade da planta, para ambos os híbridos e para plantas infectadas e não infectadas pelo fitoplasma (Figura 13). A atividade da quitinase mostrou um padrão distinto da B-1,3 glucanase (Figura 14). Neste caso, as plantas exibiram um decréscimo na atividade desta enzima até aos 40 dias, exceto plantas inoculadas do híbrido suscetível, e, em seguida, um aumento na atividade enzimática até aos 70 dias após a inoculação. A partir deste período, plantas inoculadas e não inoculadas do híbrido suscetível e resistente apresentaram redução nos níveis de quitinase. 


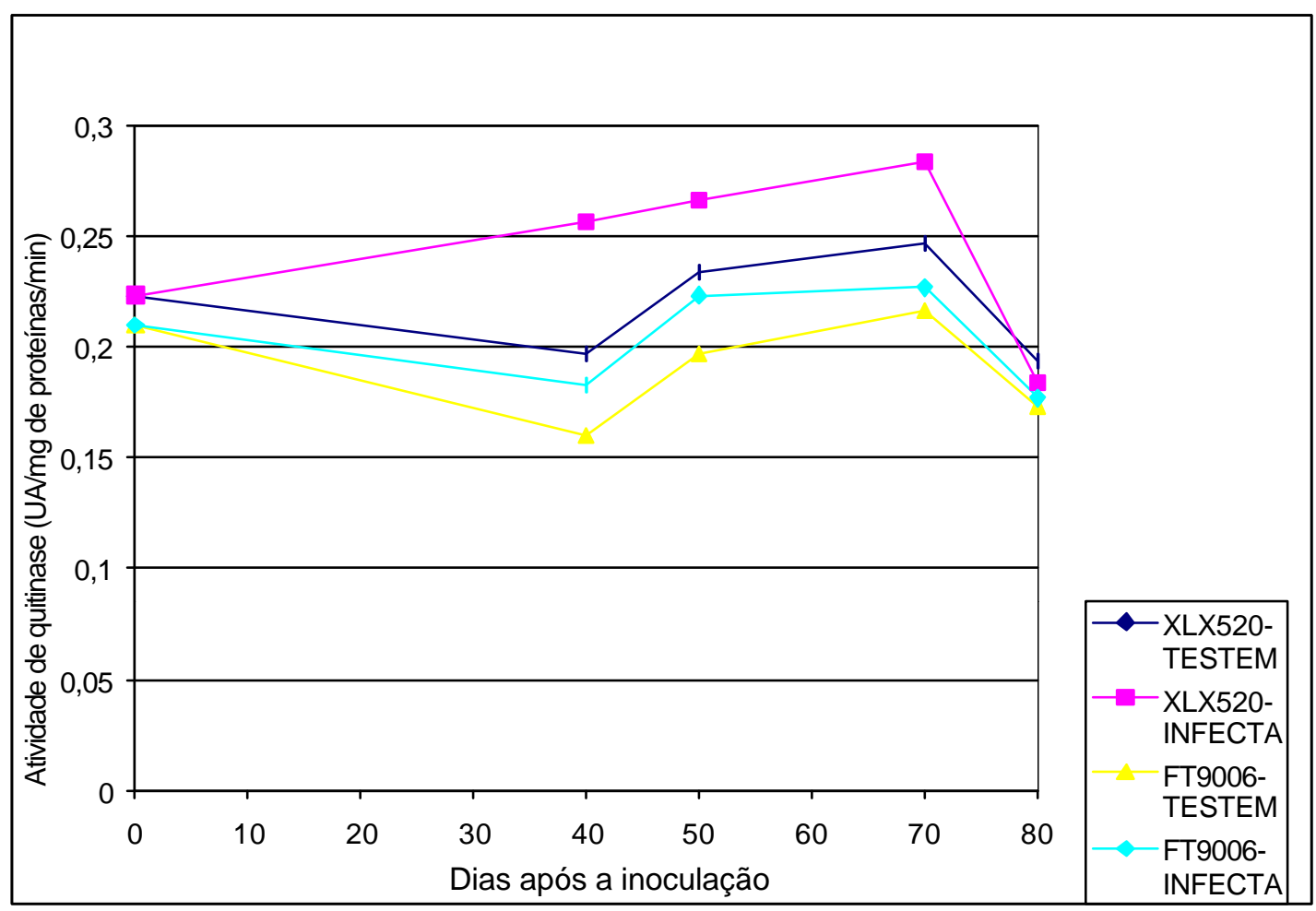

Figura 14- Atividade de quitinase resultante da infecção pelo fitoplasma, em dois híbridos de milho, XLX 520 (suscetível) e FT9006 (resistente). As plântulas de milho foram inoculadas com 10 dias de idade através de 7 cigarrinhas infectivas (Dalbulus maydis). Coeficiente de variação do ensaio $(\mathrm{CV})=8,7$ e desvio padrão $(\mathrm{DP})=0,01$

A alteração nos níveis de ß-1,3 glucanase de plantas inoculadas em relação às plantas sadias foi maior para plantas do híbrido XLX 520 (Figura 15). Em plantas inoculadas do híbrido XLX 520, a atividade desta enzima foi 58,6\% maior do que nas plantas não inoculadas, enquanto para o híbrido resistente FT 9006, a atividade foi 28,1\% maior nas plantas inoculadas (Figura 15).

Plantas inoculadas também apresentaram valores mais elevados na atividade de quitinase do que as plantas não-inoculadas, sendo que para plantas inoculadas do híbrido XLX 520, ocorreu um aumento de 13,6\% e para plantas do híbrido FT 9006, um aumento de 8,3\%. 


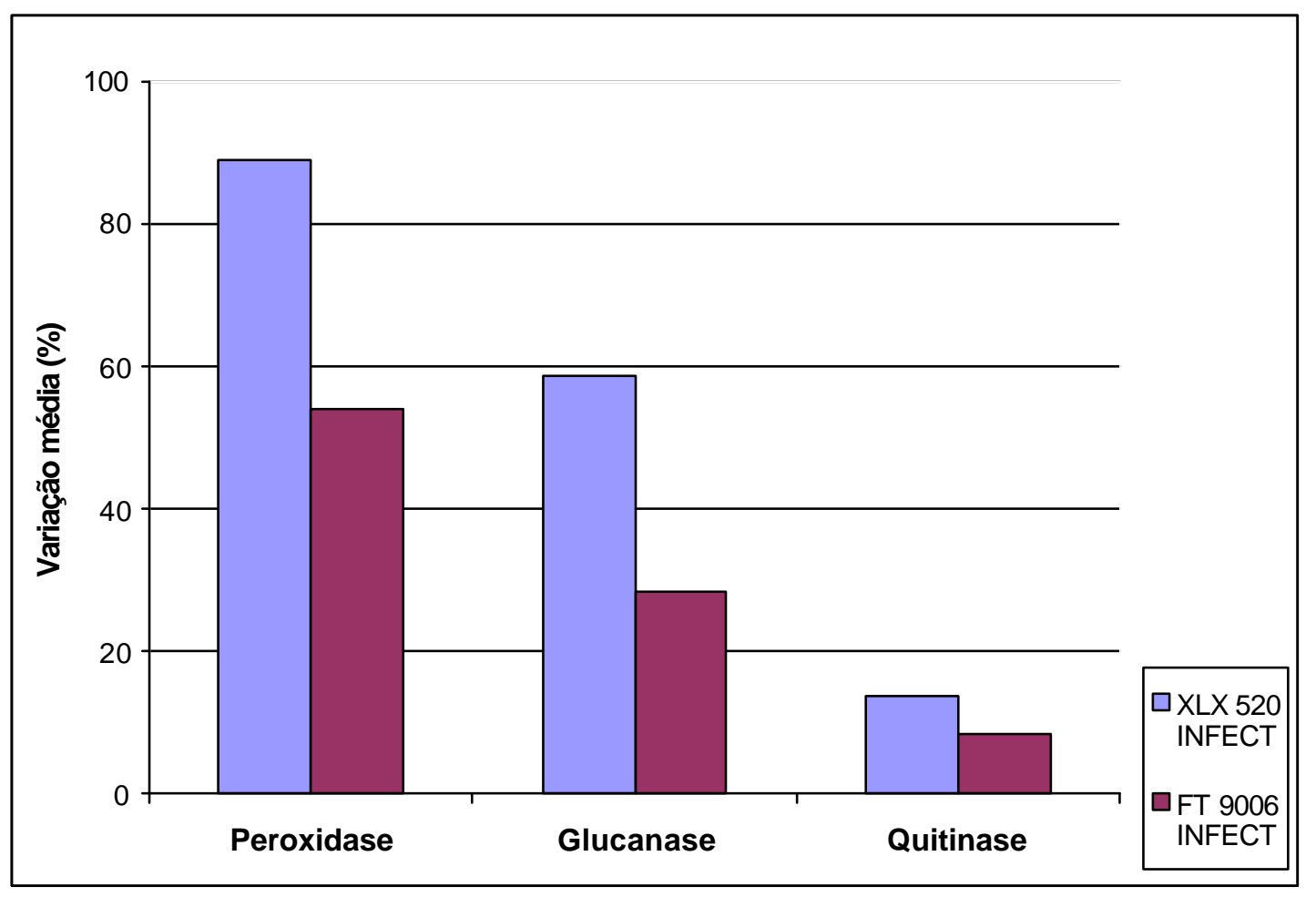

Figura 15- Variação média percentual na atividade das enzimas peroxidase, ß1,3 glucanase e quitinase em tecidos de folhas de plantas de milho inoculadas com fitoplasma em relação a plantas sadias, em dois híbridos de milho, XLX 520 (suscetível) e FT 9006 (resistente)

Plantas inoculadas de ambos os híbridos apresentaram um significativo aumento na atividade destas enzimas, sendo que este aumento foi maior para o híbrido XLX 520 (suscetível). O aumento destas enzimas conhecidas como proteínas-RP, são comuns em plantas desafiadas com fatores bióticos ou abióticos, e em geral, assim como para peroxidase, fazem parte de uma resposta geral de defesa da planta (Lozovaya et al, 1998; Cordero et al. 1994). Em milho, tem sido demonstrado que a infecção pelo Brome mosaico vírus ou tratamento com cloreto de mercúrio induz ao acúmulo de várias B-1,3 glucanases e quitinases em folhas (Nasser et al., 1988, 1990). 
Análise da expressão de ß1,3 glucanases e quitinases e fatores que afetam sua expressão são complicados, pois várias isoformas, básicas ou ácidas, têm sido encontradas para cada uma destas hidrolases. A contribuição e possível função para cada uma das isoformas específicas, tanto em plantas sadias como infectadas por um patógeno, permanece desconhecida (Cordero et al, 1994). Trabalhos conduzidos por Cordero et al. (1994), mostraram uma indução coordenada nos níveis de acúmulo de uma isoforma básica de ß-1,3 glucanase e duas isoformas ácidas de quitinase em embriões de milho em germinação inoculados com Fusarium moniliforme. Ji et al. (2000) analisaram grãos de milho infectados por Aspergillus flavus edemostraram que algumas isoformas de B-1,3 glucanase e quitinase estavam presentes em grãos com e sem sintomas, enquanto outras foram aumentadas ou induzidas apenas em grãos infectados pelo fungo. Possivelmente, algumas destas isoformas são constitutivamente expressas em folhas de milho e podem estar relacionadas ao sistema regulatório normal das plantas (Carpita, 1996). Ainda, estas isoformas podem não estar envolvidas diretamente na interação específica entre hospedeiros e patógenos, mas serem responsáveis pela defesa contra outros microrganismos que não causam doença.

Tanto para ß-1,3 glucanase como para quitinase foram observados diferentes padrões entre os diversos tecidos da planta (radículas e coleóptilos), indicando que uma importante especificidade esta correlacionada ao tipo de tecido no controle da expressão destas hidrolases (Cordero et al., 1994).

Com base no que foi exposto, é possível levantar algumas questões na tentativa de se explicar o fato de que plantas inoculadas do híbrido suscetível apresentaram um maior aumento na atividade das enzimas peroxidase, quitinases e ß-1,3 glucanases: houve alteração qualitativa (diferentes isoformas) e não apenas quantitativa de peroxidase, quitinases e B-1,3 glucanases nestas plantas?; outros tecidos vegetais analisados poderiam levar a resultados diferentes?; a inoculação com o fitoplasma induz a planta à uma resposta de defesa inespecífica?; por que mesmo com alta atividade de 
peroxidase, quitinase e $B-1,3$ glucanase plantas de milho conseguiram ser infectadas e colonizadas pelo fitoplasma?

De acordo com Ryals et al. (1996), a rapidez e a intensidade com que a reação de defesa ocorre, determinará resistência ou não ao patógeno. Assim, durante o curso da interação entre plantas de milho e fitoplasmas, efetivas isoformas destas enzimas podem não ter sido produzidas em quantidade suficiente, no tempo e local corretos.

Para melhor compreensão do comportamento destas enzimas e para demonstrar se as mesmas podem ou não estar relacionadas com a defesa destas plantas frente à infecção pelo fitoplasma, seria necessário uma avaliação qualitativa do perfil de suas isoenzimas.

Os resultados obtidos, não apenas nos ensaios conduzidos com os dois híbridos, mas também nos ensaios com os nove híbridos, mostraram claramente que plantas de milho inoculadas com o fitoplasma têm sua atividade metabólica e enzimática fortemente alteradas e que em especial as enzimas parecem fazer parte de uma resposta de defesa inespecífica das plantas. Com base nos resultados experimentais do presente trabalho, não é possível indicar a utilização das enzimas peroxidase, $ß-1,3$ glucanase e quitinase como marcadores bioquímicos de resistência. 


\section{CONCLUSÕES}

O aumento das concentrações de proteínas, açúcares redutores e fenóis em plantas de milho inoculadas revela alterações nos processos metabólicos do hospedeiro decorrentes da infecção pelo patógeno;

Alterações nas atividades de peroxidase, ß-1,3 glucanase e quitinase em plantas inoculadas com o fitoplasma do enfezamento vermelho parecem fazer parte de uma resposta inespecífica de defesa;

A redução na quantidade de clorofila total indica que o fitoplasma pode interferir no mecanismo fotossintético, podendo levar ao aceleramento do processo de senescência foliar. 


\section{REFERÊNCIAS BIBLIOGRÁFICAS}

ABELLES, F.B.; BILES, C.L. Characterization of peroxidases in lignifing peach fruit endocarp. Plant Physiology, v. 95, p. 269-273, 1991.

ABELLES, F.B.; FOENCE, L.E. Temporal and hormonal control of B-1,3 glucanase in Phaseolus vulgaris. Plant Physiolgy,v. 45, p. 395-400, 1970.

AGRIOS, G.N. Plant pathology 4. ed. San Diego: Academic Press, 1997. $635 \mathrm{p}$.

ALTSTATT, G.E. A new corn disease in the Rio Grande valley. Plant Disease Reporter, v. 29, p. 533-534, 1945.

ANAYA GARCIA, M.A. Determinacion del período mínimo y óptimo de inoculatión necessaria para que el vector Dalbulus maidis trasmite el patogeno causante del achaparramiento del maíz. Siades, v. 4, p. 9-14, 1975.

ARNON, D.I. Copper enzymes in isolated chloroplasts in Beta vulgaris. Plant Physiology, v. 24, p. 1-15, 1949.

ANWAR, M.; MAJUMDER, S.K.; SHETTY, H.S. Changes in phenolic acids in sorghum and maize with Peronosclerospora sorghi. Indian Phytopathology, v.48, n.1, p.21-26, 1995. 
ASADA, K. Ascorbate peroxidase: a hydrogen peroxidase-scavenging enzyme in plants. Physiological Plantarum, v. 85, p. 235-241, 1992.

BECKMAN, C.H. Phenolic-storing cells: Keys to programmed cell death and periderm formation in wilt disease resistance and in general defense responses in plants? Physiological and Molecular Plant Pathology, v. 57, p.101-110, 2000.

BEDENDO, I.P. Enfezamento vermelho e enfezamento pálido do milho associados a fitoplasma e espiroplasma: sintomatologia, etiologia e técnicas para a detecção e identificação destes agentes. Summa Phytopathologica, v. 25, n. 3, p. 190-196, 1999.

BEDENDO, I.P.; DAVIS, R.E.; DALLY, E.L. Molecular evidence for the presence of maize bushy stunt phytoplasma in corn in Brazil. Plant Disease, v. 81, p. 957, 1997.

BEDENDO, I.P. Detecção e identificação de fitoplasma, espiroplasma e vírus do "rayado fino"em plantas de milho, através de métodos moleculares. Piracicaba, 1997. 62p. Tese (Livre-Docência) - Escola Superior de Agricultura “Luiz de Queiróz”, Universidade de São Paulo.

BERNFELD. Amylases, alfha and beta. Methods Enymologic, v.1, p. 149-158, 1955.

BOL, J.F.; LINTHORST, H.J.M.; CORNELISSEN, B.J.C. Plant pathogenesisrelated proteins induced by virus infection. Annual Review of Phytopathology, v. 28, p. 113-138, 1990. 
BRADFORD, M.A. A rapid and sensitive method for the quantitation of microgram quantities of protein utilizing the principle of protein-dye binding. Analytical Biochemistry, v. 72, p. 248-254, 1976.

CAMPBELL, S.M.; CAMPBELL, J.B. Matemática de laboratório: aplicações médicas e biológicas. 3. ed. São Paulo: Ed. Rocca, 1986. 347 p.

CARPITA, N.C. Structure and biogenesis of the cell walls of grasses. Annual Review Plant Physiology, v. 47, p. 445-476, 1996.

CHANG, C.J. Histological investigation on phyllody in Cataranthus roseus L. Columbia, 1977. Thesis (M.S) - Universisty of Missouri.

CHANG, C.J.; LEE, I. M. Pathogenesis of diseases associated with mycoplasmalike organisms. In: SINGH, U.S.; SINGH, R.P.; KOHMOTO, K. (Ed.). Pathogenesis and host parasite specificity in plant diseases: histopathological, genetic, biochemical, and molecular basis. Pergamon Press, 1995. v. 1, p. 237-246.

COULTURE, R.M.; ROUTLEY, D.G.; DUNN, G.M. Peroxidase activity, ß-1,3glucosidase activity and phenolic levels in monogenic resistant $(\mathrm{Ht})$ and suscetiple (ht) maize tissues inoculated with Helminthosporium turcicum. Maize Genetics Cooperation Letters, v. 47, p. 160, 1973.

CORDERO, M.J.; RAVENTÓS, D.; SAN SEGUNDO, B. Induction of PR proteins in germinating maize seeds infected with the fungus Fusarium moniliforme. Physiological Molecular Plant Pathology, v. 41, p. 189-200, 1992. 
CORDERO, M.J.; RAVENTÓS, D.; SAN SEGUNDO, B. Differential expression and induction of chitinases and B-1,3-glucanases in response to fungal infection during germination of maize seeds. Molecular Plant-Microbe Interactions, v. 7, n. 1, p. 23-31, 1994.

COSTA, A.S.; KITAJIMA, E.W.; ARRUDA, S.C. Moléstias de vírus e micoplasma do milho em São Paulo. Revisão Sociedade Brasileira Fitopatologia, v. 4, p. 39-41, 1971.

DANA, B.F. Morphological and anatomical features of phyllody in varieties of tomatoes of beans. Phytopathology, v. 31, p. 168, 1941.

DAVEY, J.E.; VAN STADEN, J.; DE LEEUW, G.T.N. Endogenous cytokinin levels and development of flower virescence in Catharanthus roseus infected with micoplasmas. Physiological Plant Pathology, v. 19, p. 193,1981.

DAVIS, R.E. New perspectives on yellows diseases and their causal agents gained through molecular methods for pathogen detection and identification. Summa Phytophatologica, v. 21, p. 86-87, 1995a.

DAVIS, R.E. Fitoplasmas: fitopatógenos procarióticos sem parede celular, habitantes de floema e transmitidos por artrópodes. Revisão Anual de Patologia de Planta, v. 3, p. 1-27, 1995b.

DAVIS, R.E. Ocurrence of spiroplasma in corn stunt-infected plants in Mexico. Plant Disease Reporter, v. 57, p. 333-337, 1973.

DAVIS, R. E.; LEE, I. M. Cluster-specific polymerase chain reaction amplification of 16S rDNA sequences for detection and identification of mycoplasmalike organisms. Phytopathology, v. 63, p. 403-408, 1993. 
FANCELLI, A.L.; LIMA, U.A. Milho: produção, pré-processamento e transformação agroindustrial. Piracicaba: Coordenadoria da Indústria e do Comércio; FEAQ, 1992. 112p. (Série Extensão Agroindustrial, 5).

FRIEND, J. Plant phenolics, lignification and plant disease. Progress In Phytochemistry, v. 7, p. 197-261, 1981.

FRY, S.C Croos-linking of matrix polymers in the growing cell wall of angiosperms. Annual Review of Plant Pathology, v. 37, p.165-186, 1986.

GÁMES, R.; LÉON, P. Ecology and evolution of neotropical leafhopper-virusmaize association. In: NAULT, L.R.; RODRIGUEZ, J.G. (Ed.). The Leafhopper and Planthopper. New York, USA: John Wiley, 1985. p. 331-350.

GASPAR, T.H.; PENEL, C.; THORPE, T.; GREPIN, H. Peroxidases 1970-1980. Geneva: Universidade de Geneva, Centre de Botanique, 1982. 324 p.

GAYON, P.R. Plant phenolics. Edinburgh: Constable, 1972. 247p.

GORDON, D.T.; BRADFUTE, O.E.; GINGERY, R.E.; KNOKE, K.; LOUIE, R.; NAULT, L.R.; SCOTT, G.E. Introduction: history, geographical distribution, pathogen characteristics, and economic importance. In: GORDON, D.T.; KNOKE, K..; SCOTT, G.E. (Ed.). Virus and viruslikedisease of maize in the United States. Southern Cooperative Series Bulletim, v. 247, p. 1-12, 1981.

GRANADOS, R.R. Electron microscopy of plants and insect vectores infected with the corn stunt disease agent. Contribution Boyce Thomposon Institute, v. 24, p. 173-187, 1969. 
GRISON, R.; PILET, P.E. Cytoplasmic and wall isoperoxidases in growing maize roots. Journal of Plant Physiology, v. 118, p. 189-199, 1985.

GUNDERSEN, D.E.; LEE, I. M. Ultrasensitive detection of phytoplasmas by nested-PCR assays using two universal primers pairs. Phytophatologia Mediterrânea, v. 35, p. 144-151, 1996.

GUTHRIE, J.N.; WALSH, K.B. SCOTT, P.T.; RASMUSSEN, T.S. The phytopathology of Australian papaya dieback: a proposed role for the phytoplasma. Physiological and Molecular Plant Pathology, v.58, n. 1, p.23-30, 2001.

HAMILL, D.E.; BREWBABER, J.L. Isoenzyme polymorphism in flowering plants. IV. The peroxidase isoenzymes of maize (Zea mays.). Physiologia Plantarum, v. 22, p. 945-958, 1969.

HAMMERSCHIMIDT, T.R.; NUCKLES, E.M.; KUC, J. Association of enhanced peroxidase activity with induced systemic resistance of cucumber to Colletotrichum lagenarium. Physiological Plant Pathology, v.20, p. 73-82, 1982.

HAMMERSCHIMIDT, T.R.; KUC, J. Lignification as a mechanism for induced systemic resistance in cucumber. Physiological Plant Pathology, v. 20, p. 62-71, 1982.

HAMMERSCHIMIDT, T.R.; NICHOLSON, R.L. Resistance of maize to anthracnose: changes in hosts phenols and pigments. Phytopathology, v. 67, p. $251-258,1977$. 
HAMMOND-KOSACK, K.E.; JONES, J.D.G. Resistance gene dependence plant defense responses. The Plant Cell, v. 8, p. 1773-1791, 1996.

HARBONE, J.B. General procedures and measurement of total phenolics. In: DEY, P.M.; HARBONE, J. B. Methods in Plant Biochemistry, v. 1, p. 2-3, 1989.

HARRISON, N.A.; RICHARDSON, P.A.; TSAI, J.H.; EBBERT, M.A.; KRAMER, J.B. PCR assay for detection of the phytoplasma associated with maize bushy stunt disease. Plant Disease, v.80, p.263-269, 1996.

HOAGLAND, R.E. Biochemical responses of plants to pathogens. In: HOAGLAND, R. E. (Ed.). Microbes and microbial products as herbicides. Washington: American Chemical Society, 1990. p. 87-113.

HRAZDINA, G. Compartimentation in phenolic metabolism. Acta Horticulturae, v.1, n. 381, p. 86-93, 1994.

INSTITUTO AGRONÔMICO DE CAMPINAS: Tecnologia IAC para o milho "Safrinha". Recomendações básicas. Boletim de informações IAC, 1998.

ISAAC, S. Fungal and plant interactions. Cambridge: Chapman and Hall, 1992. 418p.

JI, C.; NORTON, R.A.; WICKLOW, D.T.; DOWD, P.F. Isoform patterns of chitinase and B-1,3-glucanase in maturing corn kernels (Zea mays L.) associated with Aspergillus flavus Milk stage infection. Journal Agricultural Food Chemistry, v. 48, p. 507-511, 2000. 
KERBY, K.; SOMERVILLE, S.C. Purification of an infection-related, extracellular peroxidase from barley. Plant Physiology, v. 100, n.1, p. 397-402, 1992.

KITAJIMA, E.W.; COSTA, A.S. Microscopia eletrônica de microrganismos do tipo micoplasma nos tecidos de milho afetados pelo enfezamento e nos órgãos da cigarrinha vetora portadora. Bragantia, v. 31, p. 75-82, 1972.

KREITLOW, K.W. Phyllody virus infection permits rooting of clover flower heads. Plant Disease Reporter, v. 47, p. 453, 1963.

KUC, J.; PRESSIG, C. Fungal regulation of disease resistance mechanisms in plants. Mycologia, v.76, p. 767-784, 1984.

LASTRA, P.; TRUJILLO, G.E. Enfermedades del maíz em Venezuela causadas por vírus y mycoplasmas. Agronomical Tropical, v. 25, p. 441-455, 1977.

LEE, I.M.; GUNDERSEN-RENDAL, D.E.; DAVIS, R.E.;BARTOSZYK, I.M. Revised classification scheme of phytoplasmas based on RFLP analyses of 16 SrDNA and ribosomal protein gene sequences. International Journal of Systematic Bacteriology, v.48, p. 1153-1169, 1998.

LEE, I.M.; DAVIS, R.E.; SINCLAIR, W.A.; de WITT, N.D.; CONTI, M. Genetic relatedness of mycoplasmalike organisms detected in Ulmus spp. in the United States and Italy by means of DNA probes and polymerase chain reaction. Phytopathology, v. 83, p. 892-833, 1993a.

LEE, I.M.; HAMMOND, R.W.; DAVIS, R.E.; GUNDERSEN, D.E. Universal amplification and analysis of pathogen 16S rDNA for classification and identification of mycoplasmalike organisms. Phytopathology, v. 83, n.8, p. 834-842, 1993b. 
LEHERER, R.E. Antifungal effects of peroxidase systems. Journal Bacteriological, v. 99, p. 361-365, 1969.

LENARDON, S.L.; LAGUNA, I.G.; GORDON, D.T.; TRUOL, G.A.; GOMEZ, J.; BRADFUTE, O.E. Identification of corn spiroplasma in maize from Argentina. Plant Disease Reporter, v. 39, p. 896-898, 1993.

LEÓN, R.; SANTAMARIA, L.; ALPIZAR, A.; ESCAMILLA.; OROPEZA, C. Physiological and biochemical changes in shoots of coconut palms affected by lethal yellowing. New Phytologist, v. 134, p. 227-234, 1996.

LEPKA, M.; STITT, M.; MOLL, E.; SEEMULLER, E. Effect of phytoplasma infection on concentration and translocation of carbohydrates and amino acids in periwinkle and tobacco. Physiological and Molecular Plant Pathology, v. 55, n. 1, p. 59-68, 1999.

LEVER, M. A new reaction for colorimetric determination of carbohydrates. Analytical Biochemistry, v. 47, p. 273-279, 1972.

LO, S.C.; DE VERDIER, K.; NICHOLSON, R.L. Accumulation of 3deoxyanthocyanidin phytoalexins and resistance to Colletotrichum sublineolum in sorghum. Physiological and Molecular Plant Pathology, v. 55, p. 263-273, 1999.

LOZOVAYA, V.V.; WARANYUWAT, A.; WIDHOLM, J.M. B1,3-Glucanase and resistance to Aspergillus flavus infection in maize. Crop Science, v. 38, p. 1255-1260, 1998. 
LUSSO, M.F.G. Alteração na atividade e no perfil eletroforético da enzima peroxidase em mesocótilos e folhas de milho (Zea mays L.) em resposta à inoculação com Helminthosporium carbonum raça 0, Helminthosporium carbonum raça 1 e à injúria mecânica. Piracicaba, 1989. 109p. Dissertação (Mestrado) - Escola Superior de Agricultura "Luis de Queiroz", Universidade de São Paulo.

MAUCH, F.; MEEHL, J.B.; STAEHELIN, L.A. Ethylene-induced chitinase and B1,3 glucanase accumulate specifically in the lower epidermis and along vascular strands of beans leaves. Planta, v.186, p. 367-375, 1992.

MARAMOROSCH, K. The occurrence of two distinct types of corn stunt in México. Plant Disease Reporter, v.39, n.12, p. 896-898, 1955.

MARAMOROSCH, K. Reversal of virus-caused stunting in plants by gibberellic acid. Science, v. 126, p. 651, 1957.

MARTINEZ, S.; CORDOVA, I.; MAUST, B.E.; SANTAMARIA, J.M. Is abscisic acid reponsable for abnormal stomatal closure in coconut palms showing lethal yellowing? Journal of Plant Physiology, v. 156, p. 319-322, 2000.

MASSOLA, N.S. Avaliação de danos causados pelo enfezamento vermelho e enfezamento pálido na cultura de milho. Piracicaba, 1998. 75p. Tese (Doutorado). - Escola Superior de Agricultura "Luiz de Queiróz", Universidade de São Paulo,

MASSOLA JUNIOR, N.S.; BEBENDO, I.P.; AMORIN, L.; LOPES, JÚNIOR. Danos provocados na cultura do milho. In : SEMINÁRIO SOBRE A CULTURA DO MILHO "SAFRINHA", 4., Assis, 1997. Anais. Campinas: IAC,CDV, 1997. p. 95-99. 
MATTEONI, J.A.; SINCLAIR, W.A. Stomatal closure in plants infected with mycoplasmalike organisms. Phytopathology, v. 73, p. 398-402, 1983.

MAUST, B.E.; ESPADAS, F.; TALAVERA.; AGUILAR, M.; SANTAMARIA, J.M.; OROPEZA, C. Changes in carbohydrate metabolism in coconut palms infected with the lethal yellowing phytoplasma. Phytopathology, v. 93, n. 8, p. 976-981, 2003.

MOHAN, R.; KOLATTUKUDY, P. E. Differencial expression of a suberizationassociated anionic peroxidase gene in near-isogenic resistant and sensitive tomato lines by elicitors of Verticillium albo-atrum. Plant Physiology, v. 92, p. 276-280, 1990.

MORRIS, S.W.; VERNOOIJ, B.; TITATARN, S.; STARRETT, M.; THOMAS, S.; WILTSE, C.C.; FREDERIKSEN, R.A.; BHANDHUFALCK, A.; HULBERT, S. Induced Resistance responses in maize. Molecular Plant-Microbe Interactions, v.11, p. 643-658, 1998.

MUSETTI, R.; FAVALI, M.A.; PRESSACO. L. Histopathology and polyphenol content in plants infected by phytoplasmas. Cytobios, v.102, n.401, p. 133147, 2000. /Resumo/

NASSER, W.; de TAPIA, M.; BURKARD, G. Maize pathogenesis-related proteins: Characterization and cellular distribution of B-1,3-glucanases and chitinases induced by brome mosaic virus infection or mercuric chloride treatment, Physiological Molecular Plant Pathology, v. 36, p. 1-14, 1990. 
NASSER, W.; de TAPIA, M.; KAUFFAMAN, S.; MONTASSER-KOUHSARI, S., BURKARD, G. Identification and characterization of maize pathogenesisrelated proteins. Four maize PR proteins are chitinases. Plant Molecular Biology, v. 11, p. 529-538, 1988.

NAULT, L.R.; BRADFUTE, O.E. Corn stunt: involvement of a complex of leafthopper-borne pathogens. In: MARAMOROSCH, K.; HARRIS, K. F. (Ed.). Leafhopper Vectors and Plant Disease Agents. New York: Academic Press, 1979. p. 561-581.

NAULT, L.R. Maize bush stunt and corn stunt: a comparison of disease symptoms, pathogen host ranges, and vectors. Phytopathology, v.70, p. 659-662, 1980.

NILCHOLSON, R.L.; HAMMERSCHMIDT, R. Phenolic compounds and their role in disease resistance. Annual Review of Ph ytopathology, v. 30, p. 369-389, 1992.

OLIVEIRA, E.; OLIVEIRA, A.C. Incidência da virose rayado fino e enfezamentos em milho em diferentes épocas de plantio. Fitopatologia Brasileira, v. 23, p.330, 1998.

OLIVEIRA, E.; WAQUIL, J.M.; FERNADEZ, F.T.; PAIVA, E.; RESENDE, R.O; KITAJIMA, E.W. Enfezamento pálido e vermelho na cultura do milho no Brasil Central. Fitopatologia Brasileira, v.23, p.45-47,1998.

OLIVEIRA, E.; WAQUIL, J.M.; PINTO, N.F.J.A. Doenças causadas por patógenos transmitidos por insetos: complexo de enfezamento/ mosaico. In: SEMINÁRIO SOBRE A CULTURA DO MILHO "SAFRINHA",4., Assis, 1997. Anais. Campinas: IAC,CDV, 1997. p. 87-94. 
OROPEZA, C.; SANTAMARIA, J.M.; ASHBURNER, G.R. A model for the pathogenicity of lethal yellowing in coconut palms (Cocos nucifera). In: International Workshop On Lethal Yellowing-like Diseases Of Coconut. Elmina, 1995. Proceedings. p. 109-118.

PASCHOLATI, S.F. Fitopatógenos: arsenal enzimático. In: BERGAMIN FILHO, A.; KIMATI, H.; AMORIN, L. (Ed.). Manual de Fitopatologia: princípios e conceitos. 3. ed. São Paulo: Agronômica Ceres, 1995. v.1, cap. 19, p.363.

PASCHOLATI, S.F.; NICHOLSON, R.L. Helminthosporium maydis suppresses expression of resistance to Helminthosporium carbonum in corn. Phytopathologische Zeitzchrift, v.107, p. 97, 1983.

PASCHOLATI, S.F.; LEITE, B. Mecanismos bioquímicos de resistência à doenças. In: LUZ, W.C. (Ed.). Revisão Anual de Patologia de Plantas, Passo Fundo: RAPP, 1994, v. 2. p. 1-51.

PASCHOLATI, S.F.; LEITE, B. Hospedeiro: mecanismos de resistência. In: BERGAMIN FILHO, A.; KIMATI, H.; AMORIN, L. (Ed.). Manual de Fitopatologia: princípios e conceitos. 3. ed. São Paulo: Agronômica Ceres, 1995. v.1, cap. 22, p. 417-453.

PASCHOLATI, S.F. Fitopatógenos: arsenal enzimático. In: BERGAMIN FILHO, A.; KIMATI, H.; AMORIN, L. (Ed.) Manual de Fitopatologia: princípios e conceitos. 3 ed. São Paulo: Agronômica Ceres, 1995. v.1, cap. 19, p.363.

PUROHIT, S.D.; SHEKHAWAT, N.S.; ARAYA, H.C. Hyperauxiny as related to Sesamum phyllody induced by mycoplasmalike organisms. Indian Journal Experimental of Biology, v.18, p. 1338, 1980. 
RONCATO, M.C.; PASCHOLATI, S.F. Alterações na atividade e no perfil eletroforético da peroxidase em folhas de milho (Zea maydis) e sorgo (Sorghum bicolor) tratadas com levedura (Saccharomyces cerevisiae). Scientia Agrícola, v. 55, n.3, p. 395-402, 1998.

RUDZINSKA, L.A; KAMINSKA, M. Cytophatological evidence for transport of phytoplasm in infected plants. Acta Societatis Botanicorum Poloniae, v. 69 , n. 4, p. 261-266, 1999. /Resumo/.

RYALS, J.; NEUENSCHWANDER, U.; WILLITS, M.; MOLINA, A.; STEINER, H.Y.; HUNT, M. Systemic acquired resistance. Plant Cell, v. 8, p. 18091819, 1996.

SCNEIDER, H. Indicator hosts for pear decline: symptomatology, histopathology, and distribution of mycoplasmalike organisms in leaf veins. Phytopathology, v. 67, p. 592-601, 1977.

SELA-BUURLAGE, M.B.; PONSTEIN, A.S.; BRESS-VLOEMANS, S.A.B.; MELCHERS, L.S.; van den ELXEN, P.J.M.; CORNELISSEN, B.J.C. Only specific tobacco (Nicotiana tabacum) chitinases and B-1,3-glucanases exhibit antifungal activity. Plant Physiological, v. 101, p. 857-863,1993.

SHIMONI, M.; BAR-ZUR.; REUVENI, R. The association of peroxidase activity and resistence of maize to Exserohilum turcicum. Journal Phytopathology, v. 131. p. 315-321, 1991.

SHIMONI, M.; BAR-ZUR.; REUVENI, R. Relation between peroxidase, B-1,3glucanase, the se gene and partial resistance of maize to Exserohilum turcicum. Canadian Journal of Plant Pathology, v. 18, p. 403-408, 1996. 
SHURTLEFF, M.C. Compendium of corn diseases. 2. ed. St. Paul: American Phytopathological Society, 1986. 105p.

STICHER, L.; MAUCHI-MANI, B.; METRAUX, J.P. Systemic acquired resistance. Annual Review of Phytopathology, v. 35, p. 235-270, 1997.

STINTIZI, A.; HEITZ, T.; PRASAD, V.; WIEDEMANN-MERDINOGLU, S.; KAUfFMANN, S; GEOFFROY, P.; LEGRAND, M.; FRITIG, B. Plant pathogenesis-related proteins and their role in defense against pathogens. Biochimie, v. 75, p. 687-706, 1993.

STRACK, D. Phenolic metabolism. In: DEY, P. M.; HARBONE, J. B. (Ed.). Plant Biochemistry. London: Academic Press, 1997. cap. 10, p. 387-416.

TOFFANELLI, C.M. Efeito do fitoplasma do enfezamento vermelho e da população de vetores infectivos sobre os sintomas e componentes da produção. Piracicaba, 2001. 68p. Dissertação (Mestrado) - Escola Superior de Agricultura "Luiz de Queiroz”, Universidade de São Paulo.

VAN LOON, L.C. Pathogenesis-related proteins. Plant Molecular Biology, v.4, p. 111-116, 1985.

VAN LOON, L.C.; VAN KAMMENEN. A. Polyacrylamide disc eletrophoresis of the soluble leaf proteins from Nicotiana tabacum var. "Samsun" and "Samsun NN" changes in protein constitution after infection with TMV. Virology, v. 40. n. 2, p. 199-211, 1970.

VANCE, C.P.; KIRK, T.K.; SHERWOOD, R.T. Lignification as a mechanism of disease resistance. Annual Review of Phytopathology, v. 18, p. 259-288, 1980. 
VANDERMEER, J.; POWER, A. An epidemiological model of the corn stunt system in Central America. Ecological Modelling, v. 52, p. 235-248, 1990.

VIZAROVA, G., VOZAR, I.; RAKUS, D. Changes of the level of free endogenous cytokinins in the above-ground parts of red currants after infestation by mycoplasm. Biolo, v. 39, p. 849, p. 1984.

WARD, E.R.; UKNES, S.J.; WILLIAMS, S.C.; DINCHER, S.D.; WIEDERHOLD, D.L.; ALEXANDER, D.C.; AHL-GOY, P.; MÉTRAUX, J.P.; RYALS, J.A. Coordinate gene activity in response to agents that induce systemic acquired resistance. Plant Cell, v.3, p. 1085-1094, 1991.

WHIRT, N.A.; WOLF, G.A. Dye-labelled sustrates forvthe assay and detection of chitinase and lysozyme activity. Journal of Microbiological Methods, v. 12, n. (3-4), p. 197-205, 1990. 